\title{
Biomass derived chars for energy applications
}

\author{
Besma Khiari $^{1}$, Mejdi Jeguirim ${ }^{2,3}$, Lionel Limousy ${ }^{2,3}$, Simona Bennici $^{2,3, *}$ \\ 1 Ecole Nationale d'Ingénieurs de Carthage, 45 rue des entrepreneurs, Tunis, Tunisie \\ Université de Haute-alsace, CNRS, IS2M UMR 7361, F-68100 Mulhouse, France \\ 3 Université de Strasbourg, France \\ * Corresponding author details: simona.bennici@uha.fr:Tel.: +33-389-336-729
}

\section{Abstract}

Biomass-derived chars present energy density values close to those of fossil fuels and therefore they are good candidates in electricity or heat production plants with only minor drawbacks compared to fossil fuels. Even if co-firing seems the most attractive solution for near-term applications, processes based on combustion and gasification (which are competing in dependence of the need of heat or electricity) are receiving renewed attention. Thanks to their high carbon content, and their high specific surface area and developed porous structure, biomass-derived chars can be treated and converted into activated carbons and applied in many different field (as energy storage materials for gaseous fuels, mainly hydrogen and methane, or as electrodes). They can constitute the raw materials for preparing synthetic graphite, which can be used in some types of batteries and fuel cells, and in carbon electrodes for electrochemical capacitors. The performances in terms of capacitance, electrical conductivity, potential, charge and discharge rates, power density, etc. have been reported to be very close to those of commercial devices. The recent progress in the activation protocols brought to higher fuel gas storage capacities, especially in cryogenic conditions and under high pressure, and opened the possibility to apply these materials in new application fields. In catalysis, advances in the use of biomass-derived chars and active carbons have been made thanks to the improvement of the modification techniques. The optimization of the engineering methodologies allows to lower the cost of the activation processes of biomass-derived chars and to tune the char properties to adapt them to the final application. The present paper aims to give a comprehensive survey of already-well-established or future potential energy applications 
of biomass-derived chars. A critical comparison of their use in different processes is reported and their modification by various catalytic, physical and chemical routes is detailed.

\section{Highlights}

- Competition of combustion and gasification in energy recovery from chars

- Tar, oil and hydrocarbon reforming increase the chars' energy recovery output

- Chars can be applied as adsorbents in fuel-gas storage systems

- Char based electrodes ensure good performances in electrochemical storage systems

- Chars can be used as catalysts in green energy applications

Key words: biomass derived chars; energy recovery by combustion; syngas; catalyst; hydrogen production; tar reforming; gas storage; electrochemical storage.

\section{Word Count: 9863}

\section{Declaration of interest: none.}

Abbreviations: $\mathrm{HHV}$, High Heating Values; $\mathrm{HHV}_{\mathrm{t}}$, High heating value of the product; $\mathrm{HHV}_{0}$, High heating value of the feed; $T_{i}$, ignition temperature; $T_{f}$, temperature corresponding to the maximum burning rate; $M_{t}$, mass of the product at time $t ; M_{0}$, initial mass of the feed; $d b$, dry basis; EC, Electric Conductivity; TG, Thermogravimetry; DTG, Derivative Thermogravimetry; $\mathrm{V}_{\max }$, maximum burning rate; $\mathrm{T}_{\mathrm{f}}$, temperature of the maximum burning rate; FR, Fuel Ratio, CI, Combustibility Index; VI, Volatile Ignitability; $\mathrm{D}_{\mathrm{i}}$, Ignition index; S, combustion characteristic index; $\eta_{M}$, mass yield ratio; $\eta_{E}$, energy yield ratio; PM, Particulate Matter; HC, hydrocarbons; $\mathrm{NO}_{\mathrm{x}}$, nitrogen oxides; PAH, Polycyclic aromatic hydrocarbons; CSR, Coke Strength after Reaction; CRI, Coke Reactivity Index; VM, Volatile Matter; BF, Blast Furnace; BDF, Biomass Derived Fuel; RDF, Refuse Derived Fuel; CGE, Cold Gas Efficiency; HE, Hot Gas Efficiency; CCE, Carbon Conversion Efficiency; ECE, Energy Conversion Efficiency; SER, Specific Energy Requirements; $\mathrm{m}_{\text {syngas }}$, mass flow rate of syngas; $\mathbf{M}_{\text {syngas }}$, molar mass of syngas; $\mathrm{m}_{\text {fue }}$, mass flow rate of feedstock; $\mathrm{LHV}_{\text {syngas }}$ and $\mathrm{LHV}$ fuel, calorific values of product gas and feedstock; $Y_{\text {dry gas }}$, dry gas yield; $C_{p}$, specific heat capacity; $T_{f}$, temperature at the gasifier exit; $\mathrm{T}_{0}$, temperature of the fuel (feedstock) entering the gasifier; $\mathrm{P}$, plasma torch power; $\mathrm{AC}$, Activated Carbon; BET, Brunauer-Emmett-Teller; SSA, Specific Surface Area; V $\mu$, microporous volume; DCFC, Direct Carbon Fuel Cell; MCFC, Molten Carbonate Fuel Cells; PEMFC, Proton-Exchange Membrane Fuel Cells; MFC, Microbial Fuel Cell. 


\section{Introduction}

Biomass-derived chars are stable solid materials with high carbon content, low density, and high porosity. Chars can be shaped into different forms (pellets, briquettes, bøeklet...) to be easily transported. Although biomass derived chars are primarily used in agriculture as soil amendment, they are recently receiving particular attention in various other fields (Table 1), such as energy production, livestock production, carbon sequestration, wastewater treatment, toxins remediation, etc. [1].

Table 1. Different applications of biomass-derived chars

\begin{tabular}{lll}
\hline Application & Char Precursor & Ref \\
\hline Reduction of soil contaminant & Broiler litter & {$[2]$} \\
Reduction of nutrient loss & Digested sugar beet tailings & {$[3]$} \\
Improvement of soil properties & Sugar cane bagasse & {$[4]$} \\
Reduction of plant health products & Dairy-manure & {$[5]$} \\
Wastewater treatment & Corncob & {$[6]$} \\
Gas treatment & Olive stones and almond shells & {$[7]$} \\
Carbon sequestration & Corn silage & {$[8]$} \\
Livestock production & Jarrah wood & {$[9]$} \\
\hline
\end{tabular}

Chars present lower $\mathrm{H} / \mathrm{C}$ and $\mathrm{O} / \mathrm{C}$ ratios than raw biomass and consequently a higher energy density. In addition, chars are hydrophobic, brittle, more easily fluidizable and they agglomerate less. Thanks to these properties the chars present many advantages, when compared to raw biomass, in transportation, storage, milling, densification and feeding. Besides, chars produced from biomass can be co-fired with pulverized coal in already existing large industrial facilities. Indeed, chars, once pulverized, can be added to coal, as their particle size distribution is much more similar to that coal than that of raw biomass. From a process point of view, the oxidation reactivity of biomass-derived chars is higher than that of bituminous coal [10]. The morphology and texture of chars are also positive characteristics for using biomass-derived chars as energy storage systems. Indeed, because chars are good adsorbents for fuel gases (mainly methane and hydrogen) or electrodes in electrochemical devices, the biomass chars seem to achieve higher 
performances than conventional systems in energy storage [11]. Unfortunately, investments to promote this application of chars are still rare. The reasons of such a reticence is probable connected to the lack of (1) industrial scale plants, (2) to the absence of complete cost analysis studies for the whole chain and (3) to the lack of a global picture of the various already made academic investigations. For this reason, the aim of this review article is to present the state of art, the recent progress, as well as the perspectives of char applications in the energy production and storage fields. This review article is also motivated by the current strong dependence of our society on to-fossil fuels and by the opportunity that chars give us for developing bioenergy markets.

\section{Chars Production, Characterization and Densification}

Different chars' production processes (pyrolysis, gasification, hydrothermal carbonization, torrefaction, etc.) can be performed starting from various feedstocks (forestry, agricultural and aquatic biomasses, livestock detritus, industrial and municipal wastes) in a wide range of installations and reactors based on different technologies of various sizes, and operating under different conditions (residence time, particle size, heating rate, final temperature, etc.).

All these parameters lead to the production of a very large panel of chars' types that, depending on their properties, can be chosen for a target final application [12]. The viability of energy related processes based on the use of chars is connected to their high carbon to ash ratio, their developed porosity and their good reducing properties. Besides, many chars are almost smokeless when burned and present relatively low and non-reactive inorganic impurities [13], with the exception of chars derived from sewage sludge, which are very rich in inorganic elements $[14,15]$. Chars' low water, sulfur and nitrogen contents are very appreciable features that make them promising substitute to commercial coals, especially because no expensive posttreatment equipment is required. Another advantage is the short time required to start the 
combustion process in the plants, when compared to the time required to start the combustion of raw biomass.

\subsection{Chars Production}

Chars can be produced by various thermal processes (Table 2) with restricted oxygen supply, preferably with slow heating rate (lower than $80{ }^{\circ} \mathrm{C} / \mathrm{min}[16]$ ), which allows long vapor residence time (ranging between 30 minutes [17] to few hours [18]) and consequently more efficient secondary cracking reactions. The most common production techniques are slow pyrolysis and carbonization that could be carried out in advanced high-tech retorts and/or pyrolysers, as well as in simple traditional pits or kilns. More recently hydrothermal carbonization is increasingly used for char production, even if its application is restraint to specific biomass sources. It consists in treating the biomass with hot compressed water instead of drying it; the resulting product is called hydrochar [19]. Microwave pyrolysis (by dielectric heating) is another technique that has been recently applied at laboratory scale $[20,21]$. This techniques is characterized by the presence of hot spots in the biomass, and brings to chars with higher HHV and specific surface area than those obtained by conventional pyrolysis [22, 23].

Table 2. Thermal processes of char production

\begin{tabular}{|c|c|c|c|c|c|c|}
\hline \multirow[t]{2}{*}{$\begin{array}{c}\text { Process } \\
\text { parameters }\end{array}$} & \multicolumn{3}{|c|}{ Pyrolysis } & \multirow[t]{2}{*}{ Gasification } & \multicolumn{2}{|c|}{ Carbonization } \\
\hline & Slow & Fast & Microwave & & Torrefaction & Hydrothermal \\
\hline $\begin{array}{l}\text { Final } \\
\text { Temperature } \\
{ }^{\circ} \mathrm{C}\end{array}$ & $350-1000$ & $>400$ & $180-600$ & $>600$ & $200-320$ & $\begin{array}{l}180-250 \\
\text { (High } \\
\text { Pressure) }\end{array}$ \\
\hline $\begin{array}{l}\text { Heating rate } \\
{ }^{\circ} \mathrm{C} / \mathrm{s}\end{array}$ & $<80$ & $100-1000$ & $5-1000$ & $\begin{array}{c}\text { Few } \\
\text { hundreds }\end{array}$ & $<50$ & 5-150 \\
\hline $\begin{array}{l}\text { Oxygen } \\
\text { Reaction } \\
\text { time }\end{array}$ & $\begin{array}{c}<2 \% \\
\text { Minutes to } \\
\text { days }\end{array}$ & $\begin{array}{c}\text { Free } \\
\text { Up to few } \\
\text { seconds }\end{array}$ & $\begin{array}{l}\text { Free } \\
\text { Seconds to } \\
\text { hours }\end{array}$ & $\begin{array}{l}20-45 \% \\
\text { Up to few } \\
\text { seconds }\end{array}$ & $\begin{array}{c}\text { Free } \\
\text { Minutes to } \\
\text { days }\end{array}$ & $\begin{array}{c}\text { Free } \\
\text { Minutes to } \\
\text { hours }\end{array}$ \\
\hline
\end{tabular}


Many pilot-scale installations equipped with moving screws, rotary drums, buffers, and other technical solutions, operate in a continuous mode. Usually, the necessary energy is supplied by burning the produced gases and vapors generated during the cracking reaction. Biomass predrying reduces the moisture content of biomass and increases the stability of the process in the reactor.

Industrial scale installations (where the integrated processes are represented in Figure 1) are already operating. Various solutions are proposed by 3RAgrocarbon (Hungary), Premier Green Energy (Ireland), Pyreg (Germany) and Biogreen (France).

Once the biomass collected, it is transported to the pyrolysis facility, where it is crushed, to reduce the particle's size, and dried (pre-processing). The pre-processes material can be then stored or directly fed to the pyrolysis/gasification/carbonization reactor. The generated gases and vapors, as well as the oils, are burned on-site for producing heat. In order to initiate the carbonization process, the humidity accumulated in the raw biomass has to be firstly evaporated. The evaporation step can take from few seconds to few minutes, and its efficiency depends on the temperature, on the installation set-up and on the size of the biomass particles. In a second step, the biomass is degasified at high temperature. Volatiles are here degassed from the biomass. The dry and devolatilized material is then kept in the hot zone of the reactor and the carbonization process can begin. The overall process can be controlled by the biomass feeding velocity, by the biomass humidity content, by the screw rotation, and by the temperature of the reactor walls. The vapors leaving the reactor present high temperature, and, depending from the kind of adopted technology, they can be burned to produce the necessary heat for pyrolysis and drying processes, or be sent to a separator (e.g. flash condenser) to produce biooil, and non-condensable gas. This last solution provides a fuel that can be used for producing energy or that can be purified and used as feedstock for other applications. Finally, the obtained 
biochar is cooled down in an absence of oxygen, to prevent auto ignition, and transported to the final destination.

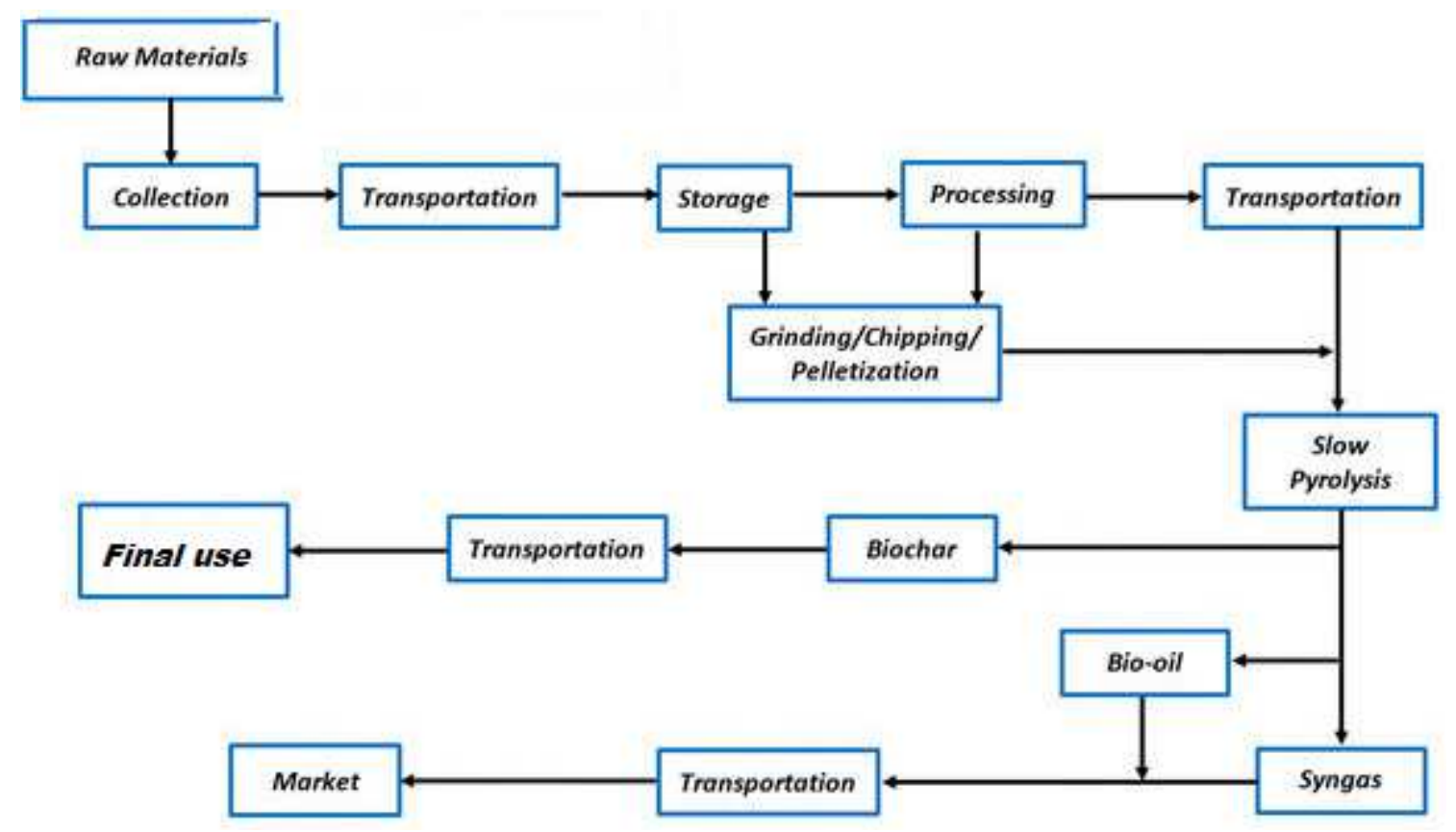

Figure 1. Industrial biochar system (Adapted from [24])

In order to enhance the performances of biochars and adapt them to the various applications, progresses in their engineering are recently being developed. Treatments as surface oxidation, amination, sulfonation, pore structure modification and recombination have been optimized in order to modify the surface functionalities and pore structure of biochar (Figure 2). The biochars' surface can be modified by adding functional groups, metal nanoparticles and inorganic nanostructures. 


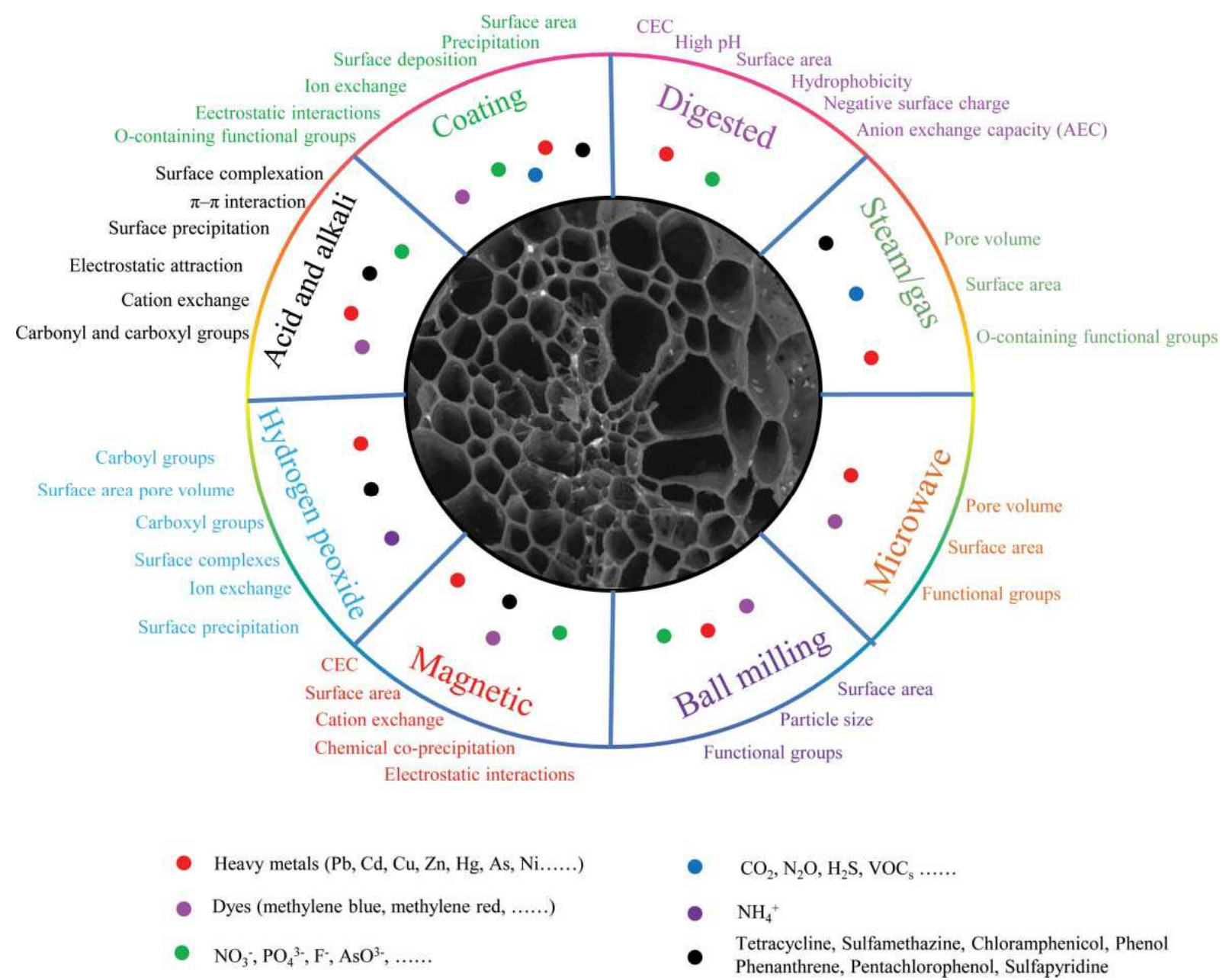

Figure 2. Biomass derived chars engineering (Reproduced with permission from [25])

\subsection{Chars' characteristics}

The biomass feedstock as well as the production process determines the final characteristics of the obtained char. The physical, chemical, textural and morphological properties of a given char impact significantly its implementation in energy production and storage processes.

\subsubsection{Energy contents and chemical composition}

Generally, the high heating values (HHV) of chars make them attractive sources for clean energy production instead of fossil-based solid fuels [26, 27]. HHVs reported in literature for chars produced from biomass vary between $10 \mathrm{MJ} / \mathrm{kg}$ (as for seaweed derived chars [28]) and 
$33 \mathrm{MJ} / \mathrm{kg}$ (for pinewood derived chars [29]), while the HHV for coal vary between 14 and 35 $\mathrm{MJ} / \mathrm{kg}[30]$.

Ashes are useless and undesirable in energy applications due to several drawbacks, such as a high quantity of fine particles emission, clinker formation, corrosion, etc. The ash content is strongly dependent on the biomass source origins. Chars deriving from slurry (chicken, swine, bovine) have usually high ash contents (up to $43.8 \%$ [31]) since the livestock is partially fed with mineral elements, while resinous softwood chars show a very low ash contents $(<1 \%)$.

The quantity of volatile organic compounds that accumulate in the gas-phase fraction during pyrolysis and carbonization, and that condensate on the surface and into the pores of the char, are systematically measured by thermo-gravimetric analyses. Condensed volatiles compounds can indeed significantly modify the functionalization of the char' surface. As an example, the high presence of volatile compounds present in cellulosic chars (up to 84\%, in Kim et al. (2015) [32]) makes them more suitable for thermal valorization than those obtained from aquatic biomass (27.5\% from algae [33]).

As nitrogen-containing compounds are generally decomposed during the char production process, especially during pyrolysis, low concentrations of $\mathrm{N}(<6 \% \mathrm{wt})$ are found in the final products. Chars, issued from vegetables (potatoes, cabbages, leeks) and slurry, contain even lower amount of nitrogen (1-4\%wt) [34]. So, the N-contents do not represent a drawback to the use of biomass derived chars for energy production. Only nitrogen contents higher than $10 \%$ can indeed become a problem due to nitrogen oxides production during thermal valorization. Moreover, no or very few sulfur is present in the chars, because it is almost completely released and eliminated during pyrolysis [34].

\subsubsection{Electric properties and surface acidity-basicity}


Electric Conductivity (EC) is the parameter used to measure the chars' salinity in soil applications. However, it is also considered as an important parameter that has to be probed for chars' used as electrodes or catalysts' supports, since it represents the ability of a solid to conduct the electric current. Furthermore, the surface acidity of a solid is also an important property that needs to be probed for chars' that might be used as electrodes or catalysts' supports [35].

In the same way, $\mathrm{pH}$ is another property playing a major role in chars' valorization (Table 3 ). Indeed, biomass derived chars can be relatively acid (chars derived from fiber materials for instance) or more basic (vegetable and garden wastes derived chars) [36]. In general, the surface chemistry is related to the presence of heteroatoms such as hydrogen, oxygen, sulfur, and nitrogen, that form surface complexes with neutral, acidic, or basic character, and that can strongly influence the chars' adsorption properties. Indeed, anhydrides and carboxylic acids, lactols, phenols, lactones, are acidic; ether groups and carbonyl are neutral functionalities [37]; while quinone, pyrone, chromene, and nitrogen groups show basic features [38]. Moreover, basicity can be also due to the presence of alkali metals, such as sodium and potassium, and alkaline earth metals, such as calcium and magnesium, in the form of carbonates $[39,40]$.

Table 3. Properties of biomass-derived chars

\begin{tabular}{|c|c|c|c|c|c|c|c|c|c|}
\hline Feedstock & $\begin{array}{c}\mathrm{C} \\
(\%)^{\mathrm{db}}\end{array}$ & $\underset{(\%)^{\mathrm{db}}}{\mathbf{H}}$ & $\begin{array}{c}\mathbf{O} \\
(\%)^{\mathbf{d b}}\end{array}$ & $\begin{array}{c}\mathbf{N} \\
(\%)^{\mathrm{db}}\end{array}$ & pH & $\begin{array}{l}\text { Ash } \\
(\%)^{\mathrm{db}}\end{array}$ & $\begin{array}{l}\text { VM } \\
(\%)^{\mathbf{d b}}\end{array}$ & $\begin{array}{l}\text { Cfix } \\
(\%)^{d b}\end{array}$ & Ref \\
\hline Pea pod & 39.32 & 4.75 & 53.3 & 2.40 & na & 3.5 & 78 & 18 & \multirow{3}{*}{ [41] } \\
\hline Cauliflower leaves & 31.8 & 3.2 & 59.4 & 4.01 & 8.84 & 18.86 & 51 & 39 & \\
\hline Orange peel & 40.43 & 4.83 & 52.90 & 1.56 & 9.84 & 39 & 70 & 24.1 & \\
\hline Apple Tree Branches & 71.13 & 4.03 & 15.05 & 1.94 & 11.4 & 7.85 & 29.85 & 62.3 & [42] \\
\hline Noxious weed & 51.76 & 1.65 & 44.41 & 2.18 & 7.83 & 19.26 & 26.13 & 48.41 & \multirow[b]{2}{*}[43]{} \\
\hline $\begin{array}{l}\text { Jatropha carcus seed } \\
\text { cover }\end{array}$ & 67.48 & 2.01 & 28.36 & 2.15 & 8.9 & 16.43 & 26.52 & 50.82 & \\
\hline Duckweed & 44.4 & 6.1 & 36.8 & 3.7 & na & 8.2 & 15.7 & 76.9 & [44] \\
\hline Poultry litter & 51.07 & 3.79 & 15.63 & 4.45 & 8.7 & 30.7 & 42.3 & 27 & [45] \\
\hline Algae & 74.5 & 4.5 & na & na & 9.1 & 68.8 & 27.5 & 72.5 & [46] \\
\hline
\end{tabular}

Cfix : Fixed Carbon; VM : Volatile Matter

\subsubsection{Morphological, Textural and Structural properties}


Specific surface area and porosity are important parameters since the charges in electrochemical storage systems are accumulated on the surface. The pores size and pores' interconnection facilitate the storage and transport of charges. Biomass derived chars are attractive materials in electrochemical energy storage due to their availability in different forms (as fibers, powders, nanotubes and nanospheres) and their developed porous network. However, carbonaceous materials with average pore size lower than $2 \mathrm{~nm}$ are not suitable as supercapacitors materials. To probe the chars specific surface and porosity, $\mathrm{N}_{2}$-adsorption at $-196{ }^{\circ} \mathrm{C}$ is commonly performed, even if, due to the presence of micro- and ultra-microporosity in chars, and the presence of high vapor pressure compounds as oils, the results obtained by this method are not always accurate and, too often, does not give reliable values [47].

The identification of the carbon types (organic, inorganic and graphitic) helps in predicting the further transformation during a thermal process. Proportionally to total carbon, graphitic carbon, which is more stable in time, is higher in hardwood chars than in softwood, manure and non-fiber biomass chars [48]. Molar ratios such as $\mathrm{H} / \mathrm{C}_{\text {org }}$ and $\mathrm{O} / \mathrm{C}_{\text {org }}$ are also indicators of the char stability. For energy applications, they should be as low as possible, and never more than 0.7 for the former and 0.4 for the latter (according respectively to DIN 51732 and DIN 51733 test methods). As for the char structure, Raman spectroscopy and X-ray diffraction spectra revealed the presence of ordered and disordered carbon rings, with dominance of highly disordered structure [49].

\subsection{Densification}

One of the major barriers to the widespread use of carbon materials derived from biomass is their low bulk density. At the expense of new capital and operating costs, densification process could overcome handling, transportation, feeding and storage difficulties. It also helps reaching good thermal conversion efficiencies $[50,51]$. These thermal qualities are inherited not only 
from char (the quality of which is itself depending on the pyrolysis operating parameters), but also enhanced by the operational conditions of the densification process [52]. For example, the net heat output of the pellet/ briquette would decrease if the sticking agent is not combustible. This is the reason why materials like starch, lignin, soil, animal dung, waste paper, gum Arabica, etc. are used in binding sawdust and chars [53]. But recently, Wu et al. (2018) successfully prepared very good quality barbecue charcoal from cotton stalks without any binders [54]. During the hydrothermal process, authors have indeed treated the biomass with hot compressed subcritical water $\left(200-260{ }^{\circ} \mathrm{C}\right)$ for a period of time ranging between 5 minutes to 8 hours.

Many technologies are available in a wide capacity range, from very small to very large and with various degrees of mechanization and automation and a wide choice of shapes and sizes of pellets and briquettes, like shown in several companies' internet sites [55, 56].

In medium to large scale briquetting technologies, mainly placed in developed countries, up to ten tons per day of medium to high quality char briquettes may be produced and distributed to regular customers, in a well-organized retail network [57]. Oppositely, hand presses and screw extruders (manual or electrical) are scarcely disseminated across rural areas of developing countries lacking electricity supply, despite the low investment needed.

In spite of obvious advantages of char briquettes, such as the relatively low price, the long burning time and the environmental sustainability, their use, instead of solid fuels, is still very limited in Sub-Saharan Africa, even compared to Asian countries, such as India or China. This is probably due to production costs (EUR $0.15-0.25 / \mathrm{kg}$ of char-briquettes, without counting purchase, transport and labor costs) [58]. Indeed, the location of the production facility (close or not to the raw material source) and/or the customer type may contribute to more than half of the briquette price. 


\section{Energy recovery from biomass derived chars}

As an energy vector, char based biomass can be used either directly, to produce power and heat, or indirectly, to produce various types of biofuel. Conversion of chars may be achieved mainly by two thermochemical methods: combustion and gasification. Moreover, the output of these two processes might be increased by using biomass-derived char based catalysts. Once densified (in form of pellets or briquettes), the carbonaceous based materials can be perfectly adapted to different reactors (fixed-bed, fluidized-bed, entrained-flow, etc.) for industrial and domestic applications. In addition, the gasification by-products can be valorized by cracking of the tars, to produce additional syngas, or by reforming the hydrocarbon and the oil, to generate hydrogen.

\subsection{Combustion of biomass derived chars}

\subsubsection{Combustion mechanisms}

The char combustion process is complex and involves various reaction steps: the oxygen transport into the boundary layer and into the numerous internal voids of the char, by convection and/or diffusion; the adsorption of oxygen on the internal and external surface; the chemical reactions at the surface (reaction involving oxygen, the char, and the various gaseous byproducts); the desorption of the combustion by-products from the surface and their diffusion towards the external surface and gas-phase $[59,60]$.

Antal and Grønli (2003) performed a deep investigation on the combustion mechanism and reported that chars, obtained under mild conditions (low temperatures), degrade following two main reactions: the pyrolysis of intact and partially-decomposed glycosyl units, and the decomposition of paraffinic and carbonyl groups. Differently, the degradation of chars obtained at high temperature is realized only by decomposition of paraffinic and carbonyl groups [61]. 
The same conclusions were reached by Islam et al. (2015) [62] and Roman et al. (2012) [63] for different biomass derived chars (Figure 43).
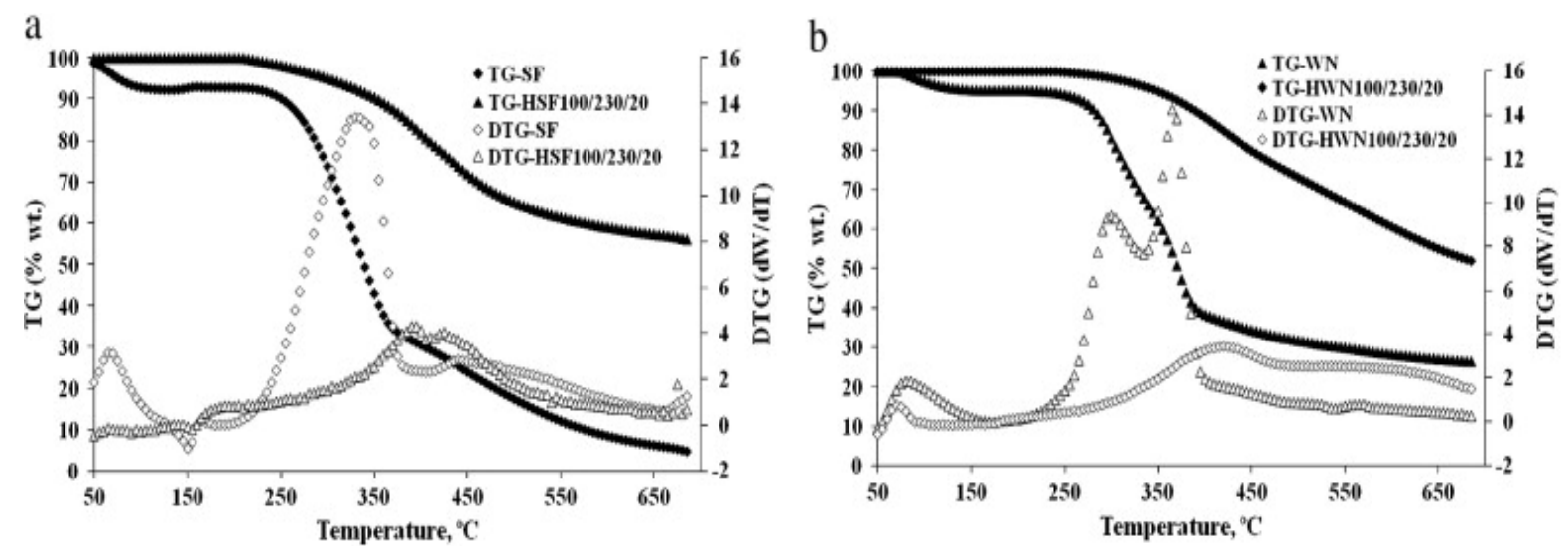

Figure 3. TG and DTG curves of precursors and respective hydrochars for a) sunflower stem and b) walnut shells under different hydrothermal conditions (Reproduced with permission from [63]).

\subsubsection{Combustion performance}

In order to be compared to other coals, chars (densified) can be described by the indicators previously defined to determine the combustibility, the reactivity and their combustion performance. Some of these indicators are experimentally determined, such as the maximum burning rate $V_{\max }$ and the corresponding temperature $T_{f}$, the ignition temperature $T_{i}$, the average combustion rate $\mathrm{V}_{\text {mean. }}$. Others are calculated, such as the fuel ratio FR, the Combustibility Index CI $(\mathrm{MJ} / \mathrm{kg})$, the Volatile Ignitability VI $(\mathrm{MJ} / \mathrm{kg})$, the Ignition index $\mathrm{D}_{\mathrm{i}}\left(\% /\left(\min .{ }^{\circ} \mathrm{C}^{2}\right)\right)$, the combustion characteristic index $\mathrm{S}\left(\%^{2} /\left(\mathrm{min}^{2} .{ }^{\circ} \mathrm{C}^{3}\right)\right)$, the mass yield ratio $\eta_{\mathrm{M}}$, and the energy yield ratio $\left(\eta_{\mathrm{E}}\right)$, on dry basis $(\mathrm{db})$ and according to the following equations:

$$
\mathrm{FR}=\frac{\text { Fixed Carbon }^{\mathrm{db}}}{\text { Volatile Matter }^{\mathrm{db}}}
$$




$$
\begin{aligned}
& C I=\frac{H^{d} V^{d b}}{F R} \times\left(115-A s h^{d b}\right) \times \frac{1}{105} \\
& \mathrm{VI}=\left[\frac{\mathrm{HHV}^{\mathrm{db}}-0.338 \text { Fixed Carbon }}{\mathrm{db}}\right] \times 100 \\
& \mathrm{D}_{\mathrm{i}}=\frac{\mathrm{V}_{\max }}{\mathrm{T}_{\mathrm{i}} \mathrm{T}_{\max }} \\
& \mathrm{S}=\frac{\mathrm{V}_{\text {max }} \times \mathrm{V}_{\text {mean }}}{\mathrm{T}_{\mathrm{i}}^{2} \mathrm{~T}_{\mathrm{f}}} \\
& \eta_{\mathrm{M}}=100 \frac{\mathrm{M}_{\mathrm{t}}}{\mathrm{M}_{0}} \\
& \eta_{\mathrm{E}}=100 \eta_{\mathrm{M}} \frac{\mathrm{HHV}_{\mathrm{t}}}{\mathrm{HHV}_{0}}
\end{aligned}
$$

where $\mathrm{M}_{0}$ and $\mathrm{HHV}_{0}$ are the mass and the high heating value of the feed, respectively. $\mathrm{t}-$ subscript indicates the same variables for the final product.

As widely reported in the literature, the reactivity of chars deriving from lignocellulosic materials is high (for instance it is the double of the reactivity of pyrolytic chars derived from tire derived fuel, ebonite, plastic materials [64], or charcoal [65]). As a consequence, their combustion starts at lower temperatures. As an example, for Hirunpraditkoon et al. (2014), ignition time of commercial coconut shell char briquette was two times longer than that of durian peel charcoal briquette [66]. Such behavior is attributed to the char property (high porosity and disordered structure) that favors short ignition times.

$D_{i}$ indicates how fast the fuel gets ignited, while $S$ expresses the fuel overall characteristics. The higher are $D_{i}, V_{\text {mean }}$ and $S$, the better is the fuel combustion behavior. It is usually assumed that when FR values are greater than 2, problems of ignition and flammability may occur. Indeed, a low fuel ratio suggests that the solid fuel easily ignites; degradation is then very fast and difficult to control, resulting in an incomplete combustion of the fuel and in smoke 
emissions. A suitable value of CI, which is used to evaluate the compatibility of a material for mixed combustion with coal, is $23 \mathrm{MJ} / \mathrm{kg}$ [67]. Finally, the minimum for VI should be 14 $\mathrm{MJ} / \mathrm{kg}$, which is the available energy provided by the total volatiles, assuming that the fixed carbon constituting the fuel sample is solely made up of pure carbon [67].

With the help of these parameters, many conclusions could be drawn from the numerous investigations [68-70]. To give an order of magnitude, the results published by Wang et al. (2014), concerning the combustion properties of briquettes of maize straw char, obtained at different final pyrolysis temperature, are hereafter presented. $D_{i}$ values ranged between 0.75 and $1.13 \% /\left(\mathrm{s}^{\circ} \mathrm{C}^{2}\right)$, while $\mathrm{S}$ varied between 0.13 and $0.9310^{-9} \%{ }^{2} /\left(\mathrm{s}^{2} .{ }^{\circ} \mathrm{C}^{3}\right)$. For chars prepared at $250{ }^{\circ} \mathrm{C}$, as final pyrolysis temperature, the mass yield ratios $\eta_{M}$ were of 79.2 and $77.5 \%$ and the energy yield ratios $\eta_{\mathrm{E}}$ were of 83.28 and $86 \%$ for Maize straw briquette and torrefied rice husk briquette, respectively. Thanks to these parameters, Conag et al. (2017) were able to predict that torrefaction of sugarcane bagasse at $250{ }^{\circ} \mathrm{C}$ would require long time (> $\left.60 \mathrm{~min}\right)$ in order to lower-down the volatile matter content and reach the desired FR, compared to only 30 min for chars prepared at 300 and $350{ }^{\circ} \mathrm{C}$. At the same time, CI was reduced from 82 to 16 $\mathrm{MJ} / \mathrm{kg}$ and the three final temperatures $\left(250,300\right.$ and $\left.350{ }^{\circ} \mathrm{C}\right)$ could improve the VI to the desired value (from 11 to $16 \mathrm{MJ} / \mathrm{kg}$ ) [67].

The analysis of these parameters values obtained by Wang et al. (2017) helped to state that blending maize straw char in briquettes with phosphorous additives would not ameliorate the combustion characteristics [71]. Definitively, the assumption that mixing mineral based additive to the char could reduce problems, such as the bed agglomeration, the fouling and the corrosion of the combustion reactors, due to the presence of alkali compounds present in green biomass, is false [72-74]. 


\subsubsection{Combustion emissions}

The viability of a combustion process is assessed not only on the bases of the efficiency parameters, but also in terms of emissions. It is widely admitted that during pyrolysis, the majority of inorganic species are retained in the char [75]; consequently, their combustion significantly reduces $\mathrm{PM}_{1}$ (and the mass of $\mathrm{Na}, \mathrm{K}$, and $\mathrm{Cl}$ in $\mathrm{PM}_{1}$ ), when compared to biomass combustion, as a consequence of volatile and $\mathrm{Cl}$ removal from the raw biomass during pyrolysis. At the same time, a considerable increase in the emission of $\mathrm{PM}_{1-10}$ as well as of $\mathrm{Mg}$ and $\mathrm{Ca}$ masses in $\mathrm{PM}_{1-10}$ is detected during the char combustion process (Table 4), probably due to the increased ash loading [76]. In any case, comparison among the emission degrees have to be made in the same combustion plant, because the emissions are not only depending by the use of chars or other fuels, but also from the used combustion technology.

Table 4. Gas emissions of different types of charcoal [77]

\begin{tabular}{lccccc}
\hline Charcoal & $\mathbf{C O}$ & $\mathbf{C O}_{2}$ & $\mathbf{N O x}$ & $\mathbf{H C}$ & $\mathbf{P M} 2.5$ \\
$(\mathbf{g} / \mathbf{k g})$ & $(\mathbf{g} / \mathbf{k g})$ & $(\mathbf{m g} / \mathbf{k g})$ & $(\mathbf{g} / \mathbf{k g})$ & $(\mathbf{m g} / \mathbf{k g})$ \\
\hline China brick-shape & 128.2 & 776. & 834.1 & 3.05 & 235.3 \\
China spheroid briquette & 300.3 & 986.8 & 161.6 & 5.27 & 368.9 \\
Indonesia sawdust hexagon briquette with hollow core & 214.7 & 878.7 & 462.1 & 1.93 & 153.9 \\
Indonesia Mangrove log & 108.5 & 855.1 & 277.0 & 9.30 & 955.7 \\
Indonesia spheroid briquette & 67.7 & 723.7 & 413.3 & 4.05 & 282.6 \\
Southeast Asian Binshotan log & 76.6 & 1225.2 & 831.9 & 3.92 & 12 \\
\hline
\end{tabular}

In order to obtain a cleaner and more efficient combustion of biomass chars, Qi et al. (2017) added various chemicals to the samples. The presence of calcium oxide and ammonium phosphate together show to reduce the alkali-metals content to different degree, while calcium carbonate promoted the retention of alkali metals. It is well-known that pyrolysis treatment reduces $\mathrm{SO}_{2}$ emissions during char combustion, but the addition of the three just-mentioned additives during the pyrolysis process, reduces these emissions to almost zero. These additives enhanced the NO emission to $1.2-3.5 \mathrm{mg} / \mathrm{g}$, that are anyway still below the restriction limits. 
For all these reasons, the three additives were judged economic and suitable for industrial applications [78].

\subsubsection{Combustion reactors and applications}

It is important to remark that the combustion mechanism, the process efficiency and the emissions level are all influenced by the combustion reactor design and configuration. Many laboratory and bench scale reactors were used in combustion tests; the corresponding main conclusions are reported in Table 5.

Table 5. Combustion of biomass-derived char in different reactors

\begin{tabular}{|c|c|c|c|}
\hline Reactor & $\begin{array}{l}\text { Char based } \\
\text { biomass }\end{array}$ & Main conclusions & Ref \\
\hline $\begin{array}{l}\text { Drop-tube } \\
\text { furnace }\end{array}$ & Mallee bark & Unimodal particle size distribution of $\mathrm{PM}_{10}$ & [76] \\
\hline $\begin{array}{l}\text { Fluidized } \\
\text { bed reactor }\end{array}$ & $\begin{array}{l}\text { Robinia } \\
\text { pseudoacacia }\end{array}$ & $\begin{array}{l}\text { Complete conversion to } \mathrm{CO} \text { or } \mathrm{CO}_{2}: 50 \% \text { direct } \\
\text { coarse char combustion and } 50 \% \text { during subsequent } \\
\text { post-combustion in the bed }\end{array}$ & [79] \\
\hline \multirow[t]{3}{*}{$\begin{array}{l}\text { Fluidized } \\
\text { bed reactor }\end{array}$} & $\begin{array}{l}\text { Pine seed shells } \\
\text { Olive husk } \\
\text { Wood chips }\end{array}$ & $\begin{array}{l}\text { Extensive primary and secondary fragmentation of } \\
\text { char particles ( } 25 \text { to } 45 \% \text { of fixed carbon } \\
\text { consumption due to percolative fragmentation). }\end{array}$ & [80] \\
\hline & & $\begin{array}{l}\text { The biogenous character of the char fuels: } \\
\text { significant role in the afterburning of the attrite } \\
\text { fines. }\end{array}$ & \\
\hline & & $\begin{array}{l}\text { Significant particle shrinkage after devolatilization } \\
\text { (development of highly porous structure } \\
\text { characterized by macropore dominance) }\end{array}$ & \\
\hline $\begin{array}{l}\text { Fixed bed } \\
\text { reactor }\end{array}$ & Olive wastes & Complete conversion of Carbon & [81] \\
\hline \multirow{3}{*}{$\begin{array}{l}\text { Laminar } \\
\text { flow } \\
\text { reactor }\end{array}$} & $\begin{array}{l}\text { Pine } \\
\text { Switch grass }\end{array}$ & $\begin{array}{l}\text { Removal of amorphous material and release of } \\
\text { oxygen and hydrogen-rich gases }\end{array}$ & [82] \\
\hline & & $\begin{array}{l}\text { Inorganic transformations: vaporization (namely } \\
\text { potassium and sodium), surface migration and } \\
\text { coalescence, embodiment of metals (such as Ca) } \\
\text { into silicate, etc. }\end{array}$ & \\
\hline & & $\begin{array}{l}\text { Shift of amorphous structure of the inorganic } \\
\text { compounds to crystalline form }\end{array}$ & \\
\hline
\end{tabular}




$\begin{array}{lll}\begin{array}{l}\text { Chemical } \\ \text { looping } \\ \text { combustor }\end{array} & \begin{array}{l}\text { Swedish wood } \\ \text { Mexican } \\ \text { petcoke }\end{array} & \begin{array}{l}\text { High carbon capture rate (93-97\% for wood char) } \\ \text { High gas conversion }(90-95.3 \%)\end{array} \\ \begin{array}{l}\text { Blast } \\ \text { furnace }\end{array} & \begin{array}{l}\text { Sawdust char } \\ \text { pellets }\end{array} & \begin{array}{l}\text { Low NOx emissions of torrefied pellets in } \\ \text { comparison with raw sawdust explained by the } \\ \text { release of volatiles or N-containing volatiles such } \\ \text { as } \mathrm{HCN} \text { and } \mathrm{NH}_{3} \text { during pyrolysis of char it is } \\ \text { quickly combusted with the raw cane }\end{array}\end{array}$

The tested reactors are adapted to operate in industrial contexts, but not for domestic applications. Even if cooking and heating needs are still assured by traditional stoves in rural regions, improvements, to reach higher targets of energy efficiency and low emissions, are needed. Indeed, actual concerns are in particular related to hazardous particles and pollutant gases emission (particle matter, black carbon, $\mathrm{CO}, \mathrm{NO}_{\mathrm{x}}, \mathrm{SO}_{2}, \mathrm{PAH}$ ), that might cause health risks (indoor air pollution), and environmental problems (greenhouse gases emissions, air pollution, deforestation) [85]. According to Winijkul and Bond (2016), clean-fuel may reduce emissions by 18 to $25 \%$ depending on the pollutant considered [86], while stove improvements, such as adding chimney, retaining heat, plugging fans, etc. may lower emissions by 25 to $82 \%$, and PM by 95\% [87-90]. The stove prices depend by many factors and, for example, they can vary from US \$2 in Ethiopia to US \$15 in Guatemala [91].

\subsubsection{Iron and steel production}

In the industrial field, the goals in using char feedstock are focused on energy-saving, low emission release, and lowering of the energy production cost. The contribution of the transition towards bio-sourced fuels, on the various points of improvement, can be clearly demonstrated in the iron and steel production industries, where sustainable biomass-based chars/charcoals have fully and/or partially replaced the fossil-based coals and metallurgical coke, in the various steps of the process chain (Table 6). 
Table 6. Application of biomass-based chars in iron and steel industry

\begin{tabular}{|c|c|c|}
\hline $\begin{array}{l}\text { Biomass based } \\
\text { char }\end{array}$ & Main features/results & Ref \\
\hline \multicolumn{3}{|c|}{ Coke making } \\
\hline $\begin{array}{l}\text { Torrefied: } \\
\text { kraft lignin from } \\
\text { pulp/paper } \\
\text { industry }\end{array}$ & $\begin{array}{l}\text { Generally lowers the maximum fluidity achieved in the coal- } \\
\text { biochar blend: biochars do not pass through the plastic phase } \\
\text { during the coking process. The formation and stability of the } \\
\text { coke matrix is maintained. }\end{array}$ & $\begin{array}{l}{[92-} \\
94]\end{array}$ \\
\hline \multicolumn{3}{|l|}{$\begin{array}{l}\text { woody } \\
\text { components }\end{array}$} \\
\hline \multicolumn{3}{|l|}{ cellulose } \\
\hline \multicolumn{3}{|l|}{ lignin } \\
\hline \multicolumn{3}{|l|}{ xylan } \\
\hline $\begin{array}{l}\text { Up to } 15 \% \\
\text { charcoals }\end{array}$ & $\begin{array}{l}\text { Metallurgical coke with adequate quality (fluidity in the range of } \\
400-1000 \text { dial division per minute (ddpm) }\end{array}$ & [95] \\
\hline $\begin{array}{l}\text { Up to } 10 \% \text { of } \\
\text { highly } \\
\text { carbonized } \\
\text { biochars }\end{array}$ & $\begin{array}{l}\text { Increase in Reactivity attributed to high presence of calcium in the } \\
\text { blend. }\end{array}$ & \\
\hline \multirow{2}{*}{$\begin{array}{l}\text { Torrefied } \\
\text { biomass }\end{array}$} & Small contraction for coarse torrefied biomass; & {$[96]$} \\
\hline & No contraction for particle sizes $<0.25 \mathrm{~mm}$ & \\
\hline \multirow[t]{3}{*}{$\begin{array}{l}\text { Different } \\
\text { concentrations of } \\
\text { charcoal added to } \\
\text { coal blends }\end{array}$} & $\begin{array}{l}\text { The wall coking pressure decreases significantly (especially for } \\
\text { smaller charcoal particles as compared to pure coal blends), due } \\
\text { to the gases escaping from the plastic layer in the presence of } \\
\text { inert materials. }\end{array}$ & [97] \\
\hline & Coarse torrefied biomass particles increase the wall pressure & \\
\hline & Oven pressure decrease with finer particles. & \\
\hline $\begin{array}{l}\text { Chestnut and } \\
\text { pine }\end{array}$ & $\begin{array}{l}\text { Post-reaction strength (Coke Strength after Reaction CSR) of coke } \\
\text { decreasing and Coke Reactivity Index CRI increasing }\end{array}$ & [98] \\
\hline \multicolumn{3}{|l|}{$\begin{array}{l}\text { Sawdust chars } \\
(1-5 \text { wt. } \%)\end{array}$} \\
\hline \multirow[t]{2}{*}{ Biochar } & $\begin{array}{l}\text { For replacement in coke-making, optimal charcoal characteristics: } \\
\mathrm{VM}<10 \% \text {, size }<1 \mathrm{~mm} \text {, density }>700 \mathrm{Kg} / \mathrm{m}^{3} \text { and low alkali } \\
\text { content. }\end{array}$ & [99] \\
\hline & Net $\mathrm{CO}_{2}$ emissions saving of $1-5 \%$ & \\
\hline \multirow[t]{2}{*}{ Charcoal } & $\begin{array}{l}\text { For BF nut coke replacement: } \mathrm{VM}<7 \% \text {, high density, sizes }<(20- \\
25) \mathrm{mm} \text {. }\end{array}$ & $\begin{array}{l}{[100} \\
]\end{array}$ \\
\hline & $\begin{array}{l}\text { - } \mathrm{CO}_{2} \text { emission savings estimated } \sim 3-7 \% \text { (in commercial mini } \mathrm{BFs} \\
\text { and industrial trials in large } \mathrm{BFs} \text { ) }\end{array}$ & \\
\hline
\end{tabular}




\begin{tabular}{|c|c|c|}
\hline $\begin{array}{l}20-50 \% \text { chars } \\
\text { from sunflower } \\
\text { husks }\end{array}$ & $\begin{array}{l}\text { Sintering time decreases from } 440 \mathrm{~s}(0 \% \text { husk) to } 415 \mathrm{~s}(20 \% \\
\text { husk) and } 387 \mathrm{~s}(50 \% \text { husk); low heat capacity and higher } \\
\text { reactivity of the sunflower husk chars } \\
\text { No change in combustion efficiency for up to } 20 \% \text { husk } \\
\text { replacement }\end{array}$ & \\
\hline $\begin{array}{l}\text { Red gum } \\
\text { charcoal }\end{array}$ & Satisfactory sinter & [102] \\
\hline \multicolumn{3}{|l|}{$\begin{array}{l}\text { Charcoal } \\
\text { prepared from } \\
\text { prickly acacia }\end{array}$} \\
\hline \multirow[t]{2}{*}{$\begin{array}{l}\text { Biomass-based } \\
\text { chars }\end{array}$} & $\begin{array}{l}\text { Increasing substitution rates resulted in lower sinter yields and } \\
\text { productivity }\end{array}$ & [103] \\
\hline & $\begin{array}{l}\text { Decrease in maximum temperature and holding time due to higher } \\
\text { reactivity }\end{array}$ & \\
\hline \multirow[t]{2}{*}{ Charcoals } & $\begin{array}{l}\text { Low sinter strength along with decreasing of the bulk density, well } \\
\text { defined combustion and sintering zones by operating with blast } \\
\text { furnaces. }\end{array}$ & [104] \\
\hline & The share of charcoal in iron ore sinters limited to $25 \mathrm{wt} . \%$ & \\
\hline \multirow{2}{*}{$\begin{array}{l}\text { Up to } 40 \% \\
\text { Charcoal } \\
20 \% \text { straw chars }\end{array}$} & $\begin{array}{l}\text { Charcoals provided better results than straw chars, up to } 40 \% \text { bio- } \\
\text { charcoals (and only } 20 \% \text { straw chars) could be used to replace }\end{array}$ & $\begin{array}{l}{[105,} \\
106]\end{array}$ \\
\hline & $\begin{array}{l}\text { Reduced bulk density of the sinters; } \\
\text { Combustion temperatures achieved relatively quickly in these } \\
\text { sinters due to rapid heating and lower thermal loads }\end{array}$ & \\
\hline \multirow{2}{*}{$\begin{array}{l}\text { Waste carbons, } \\
\text { Biobased } \\
\text { charcoals and } \\
\text { chars }\end{array}$} & $\begin{array}{l}\text { Agglomerating fine powders with iron ore fines with the use of } \\
\text { binder }\end{array}$ & [107] \\
\hline & Higher Iron oxide reduction rates & \\
\hline Wood straw fiber & Higher Iron oxide reduction rates & [108] \\
\hline \multicolumn{3}{|l|}{ Sawdust } \\
\hline \multicolumn{3}{|l|}{ Rice crust chars } \\
\hline \multicolumn{3}{|l|}{ Charcoal } \\
\hline Charcoal & $\begin{array}{l}\text { Replacement charcoal needs to have } \mathrm{VM}<3 \% \text {, densities }>700 \\
\mathrm{Kg} / \mathrm{m}^{3} \text {, small sizes }<0.3 \text { to } 3 \mathrm{~m}\end{array}$ & [110] \\
\hline & $\begin{array}{l}\text { Net } \mathrm{CO}_{2} \text { emissions reductions of } 5-15 \% \text {. } \\
\text { For carbon composites, biochars need to have high } \\
\text { strength }>500 \mathrm{~N}, \mathrm{VM}<5 \% \text { and sizes typically } \sim 75 \mu \mathrm{m} \text { and could } \\
\text { achieve net } \mathrm{CO}_{2} \text { emissions reductions of } 3-7 \%\end{array}$ & \\
\hline
\end{tabular}




\begin{tabular}{|c|c|c|}
\hline Biochars & $\begin{array}{l}\text { Rates can reach up to } 200 \mathrm{~kg} \text { for producing } 1000 \mathrm{~kg} \text { of hot metal } \\
\text { Higher rates can seriously impact on furnace stability }\end{array}$ & $\begin{array}{l}{[111,} \\
112]\end{array}$ \\
\hline $\begin{array}{l}\text { Pine, chestnut } \\
\text { chips, black } \\
\text { poplar torrefied } \\
\text { in at } 240-300{ }^{\circ} \mathrm{C} \\
\text { with } 11-43 \text { min } \\
\text { residence time }\end{array}$ & $\begin{array}{l}\text { Grindability is improved with higher torrefaction temperature and } \\
\text { with longer residence time. } \\
\text { Flow behavior comparable to that of coals } \\
\text { The relative proportion of chars in blends could range between } 10 \\
\text { and } 50 \text { wt.\% without any drawback. }\end{array}$ & $\begin{array}{l}{[113]} \\
{[114,} \\
115]\end{array}$ \\
\hline $\begin{array}{l}\text { Pine and birch } \\
\text { charcoals } \\
\text { produced at } \\
520^{\circ} \mathrm{C}\end{array}$ & & \\
\hline Biochars & $\begin{array}{l}\mathrm{CO}_{2} \text { reactivity of biochars (VM } 21.9 \% \text { ) higher than that of a high } \\
\text { volatile }(38.7 \%) \text { coal, due to the high porosity and disordered } \\
\text { carbon structure of biochars. }\end{array}$ & [116] \\
\hline Eucalyptus chars & $\begin{array}{l}\text { Higher level of burnout with all levels of VM drop-tube furnace) } \\
\text { than injection coals at } 1300^{\circ} \mathrm{C} \text { in a wide range of oxygen levels. }\end{array}$ & [117] \\
\hline Biochars & $\begin{array}{l}\text { Injection of pulverized biochar particles }(<75 \mu \mathrm{m}) \text { into a BF could } \\
\text { reduce } \mathrm{CO}_{2} \text { emissions between } 18 \text { and } 40 \% \\
\text { Complete replacement of coals with biochars increases operating } \\
\text { costs by } 5-16 \%\end{array}$ & $\begin{array}{l}{[118,} \\
119]\end{array}$ \\
\hline Biochars & $\begin{array}{l}\text { Biochars need to have high VM } 10-20 \% \text {, low ash content }<5 \% \\
\text { and low level of alkalis. } \\
\mathrm{CO}_{2} \text { emissions decreased up to } 19-25 \% \text {. } \\
\text { In mini and large BFs, physical parameters of biochars, such as } \\
\text { porosity, grain size distribution, and specific surface do not have } \\
\text { a negative effect on charcoal injection rates. }\end{array}$ & {$[120]$} \\
\hline
\end{tabular}

\section{Charge carbon and slag foaming agent in electric arc furnace (EAF)}

Biochars from agricultural waste

Biochars

Agricultural waste (coconut shells and palm shells) chars
Fixed carbon, ash content and volatile matter : key parameters to use biochars as a slag foaming agent, either by itself or as cokebiochar blends

High reactivity biochars produce higher levels of slag foaming than coke.

Mineral impurities in biochars can affect slag chemistry, slag viscosity and surface tension.

For adequate carbon transfer into slag, low density of biochars may necessitate briquetting or pelletizing.

Strong influence on the combustion performance and carbon/slag interactions including $\mathrm{FeO}$ reduction, gas generation and its entrapment within the slag as well as the enhancement of the slag volumes.

Extensive reactions in the gas phase and carbon/slag interactions for $100 \%$ palm chars. 
Biochar fines

Biochars
The combustion burnout of coke/agricultural blends higher than the burnout of coke and raw agricultural waste alone.

Palm chars: high slag volumes but slow rates for iron oxide reduction. Slower rates of gas generation made it easier for slag to trap gases and to generate sustained levels of slag foaming. A balance between iron oxide reduction and foaming need to be established for optimizing furnace efficiency and operations.

No negative impact on steel quality, slag chemistry or slag foaming, but carburization of molten iron below acceptable levels (plant trials), attributed to high combustion rates of biochars in a limited time

Possible of control reactivity and combustion behavior of biochars by briquetting with water and molasses

No significant differences in metal and slag quality in comparison with coal (industrial-scale trials of charging and injection)

Issues of handling, charging, dispersing of low density powders, and intense flame emissions

Inadequate and limited slag foaming affected by the penetration of biochar in the slag during injection trials.

Biochars require low VM (2-7\%), low moisture content (1-7\%), particle size $\sim 0.5$ to $5 \mathrm{~mm}$ in industrial trial.

\section{Pre-reduction}

Biochar based Higher degree of reduction in 60 min attributed to the higher rate [127] composites of gasification for biochars.

Biochar based Small effect of particle size on the reduction rate; small composites enhancement in of the reaction kinetics for smaller char particles, attributed to their higher surface area.

Biomass char Isothermic reduction of composite briquettes to metallic iron in the presence of $\mathrm{H}_{2}-\mathrm{CO}$ gas mixtures.

Lower amounts of reduced iron.

Iron concentration in biochar-based composite pellets reached $95 \%$, the temperature of the direct reduction increased to $1100{ }^{\circ} \mathrm{C}$.

Relative proportion of $\mathrm{CO}$ in the gas mixture: negative influence on the overall reduction behavior and metal quality.

Biochar based Working volumes needed up to $6000 \mathrm{~m}^{3}$

self-reducing pellets

Despite all the advantages that the employment of biomass-based chars can bring to the metallurgic sector (reductions in $\mathrm{CO}_{2}$ and $\mathrm{SO}_{2}$ generation, improvements in the quality of hot metal, reduction in slag volumes), some issues have still to be solved (Table 4). Indeed, basic 
characteristics of solid biomass-based chars are significantly different from those of fossilbased coals and cokes. For example, highly reactive biomass-based reducing agents provide high burnout during blast furnace BF injection, but have also a negative influence on their sintering capacity.

\subsubsection{Heat and power generation}

Another major application of biomass based char, as a renewable fuel, is in the power and heat industry. Characteristics such as "zero balance" of $\mathrm{CO}_{2}$ emissions, as well as the interesting calorific value, the high carbon content, the low moisture, ash and volatiles contents play in favor of firing and/or co-firing processes in electricity generators. Moreover, the extending generation life assets, the avoiding stranded and the early remediation costs, accompanied to increasing revenues, are other financial benefits that these carbonaceous materials can bring by their use in power plants.

In rural areas, small-scale char-based thermal power plants may solve supply and transmission issues, and small industries, like dairy milk production or cereals milling, can be created [130]. Also larger and consistent fuel demands of bigger industries can be satisfied by biomass-derived chars. As an example, the works of Cunningham et al. (2016) proved that fecal sludge char could potentially be used as a solid fuel in power plants and cement kilns [131].

\subsubsection{Application in automotive diesel engines}

Char can be also used as liquid fuels for potential applications in stationary or nomade transportation diesel engines [133].

The char based fuels are mainly constituted of char-water and char-hydrocarbon mixtures, but an innovative fuel derived from micronized chars has been recently added to the family of liquid biofuels (Figure 4). These solutions are safe (especially the char-water mixtures), as they are not flammable and eco-friendlier than other fuels usually used for vehicles, ships, agricultural 
trucks, etc. transport applications and for feeding back-up electricity supply devices [134]. For example, slurry fuels can have a significant advantage as water reduces the flame temperature and $\mathrm{NO}_{\mathrm{x}}$ emission, with only a small energy loss due to water vaporization. The char-fuel is easily stored in tanks and pumped, and there is no risk of dust explosions.

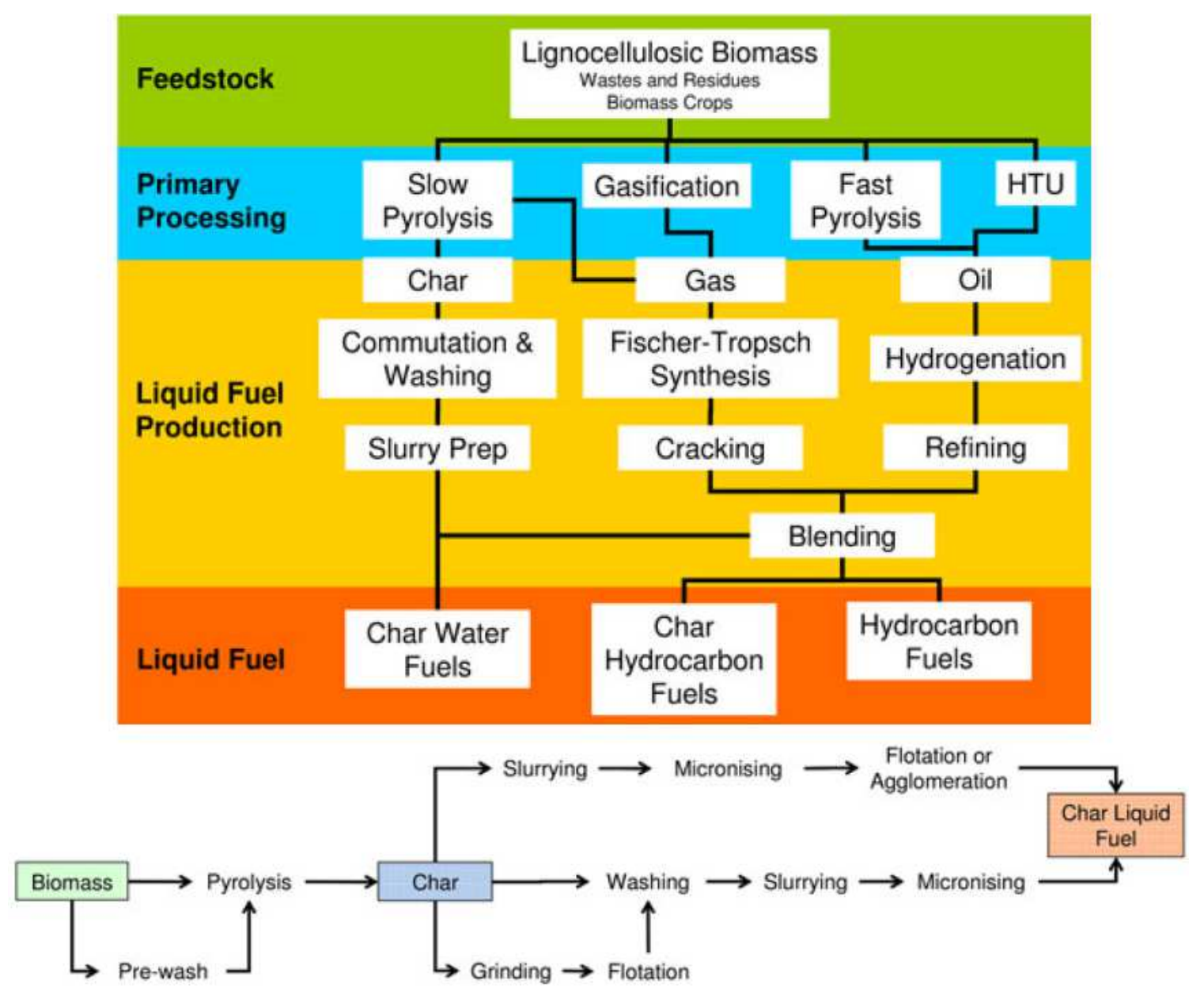

Figure 4. Pathways from biomass-derived chars to liquid fuels (Reproduced with permission from [133])

Char-water fuel mixtures are obtained by crushing (to a particle size smaller than $70 \mu \mathrm{m}$ ) and suspending the char in water (in presence of a suitable surfactant to guaranty the stability of the suspension). On the other hand, char-hydrocarbons mixtures need to be processed at high pressures. This supplementary cost is regained by the high energy density and to the possibility to use a large panel of configuration of the solid charge (content, particle size, volatility, etc.) 
[134]. Besides, these systems do not need any pilot fuel injection for lower speed operation. Nevertheless, these aspects should be deeply investigated in order to develop these new automotive fuel systems [135]. Indeed, more target efforts have to be made for reducing the particle sizes, the amount of ash production, and hardening the injectors [136]. A major drawback in the implementation of this kind of fuels for power station applications, is the necessity to produce slurries highly charged in char (to enhance the energy content) with a viscosity compatible to the pumping procedures and atomization of the fuel.

\subsubsection{Barriers to biomass char combustion}

Despite the high quality of biomass-based chars as fuel in many fields, a barrier to the wider industrial utilization of chars as energy source is the still too high price and the limited number of suppliers, when compared to fossil-based carbonaceous resources [137]. In fact, research is mostly concentrated on woody charcoal, and only little work is performed on other biomass residues, even if they can be less expensive and more widely accessible. To overcome the financial issue, economic analysis suggested that the transition to biomass derived chars would have a higher chance of success if developed as an add-on to existing business, where production facilities (land, building, back office staff, etc.) can be shared.

Moreover, other technical problems related to the use of biomass derived chars can occur in the combustors:

- irregular morphology can complicate operations such as handling or feeding;

- vaporization and recondensation of alkali metals that can lead to the release of submicron aerosols and to fouling and corrosion of the burner surfaces [133] ; 
- conversion of calcium and/or alkali metals into silicates that mitigate the ash softening temperature, consequently increasing the ash deposit [82], etc.

Investigations have been performed to find solutions to all these issues. For example, leaching and mechanical separation processes might be key technologies for reducing alkali metal and mineral content from biomass, in order to produce fuel of higher quality.

\subsection{Gasification of biomass derived chars}

\subsubsection{Gasification mechanisms}

Gasification is a thermochemical process that converts carbonaceous materials into useful products, such as gaseous fuels or chemical feedstock. This section focuses on power and biofuel recovery by using already available gasification technologies.

Gasification of biomass char includes several exothermic (methanation, steam-methane reforming) and endothermic reactions (oxidation, reduction) between the char and the gasifying agents (water, $\mathrm{CO}_{2}, \mathrm{O}_{2}$ ), in order to convert it into gaseous by-products (mainly $\mathrm{H}_{2}$ and $\mathrm{CO}$ ), also called syngas [138] (Figure 5).

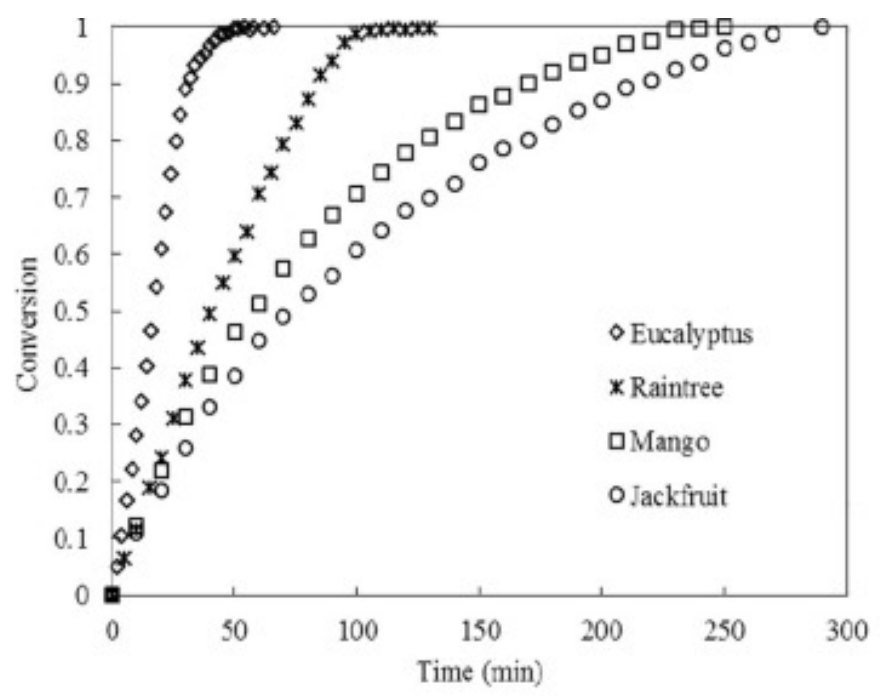


Figure 5. Conversion of different biomass-based chars for $\mathrm{CO}_{2}$ gasification at $800{ }^{\circ} \mathrm{C}$

(Reproduced with permission from [139])

The first step of the process is pyrolysis, during which the char material is decomposed into secondary chars (carbon and ashes), gases $\left(\mathrm{CH}_{4}, \mathrm{CO}_{2}, \mathrm{CO}\right)$ and tars, at around $300-650^{\circ} \mathrm{C}$ in the absence (or very low concentration) of oxidizing agents. The residual solid matrix, obtained after pyrolysis, is then gasified (usually in the 700 to $1000^{\circ} \mathrm{C}$ range) with an external gasifying agent $\mathrm{CO}_{2}, \mathrm{H}_{2} \mathrm{O}, \mathrm{O}_{2}$, air, to produce $\mathrm{H}_{2}$ and $\mathrm{CO}$ (syngas).

Acquiring information on the char reactivity is necessary to optimize the gasifier. Biomass derived chars are more reactive, present a higher content of volatiles, and require lower gasification temperature than other carbonaceous materials, like coals and raw biomass (Table 7).

Table 7. Biomass-based char application in gasification

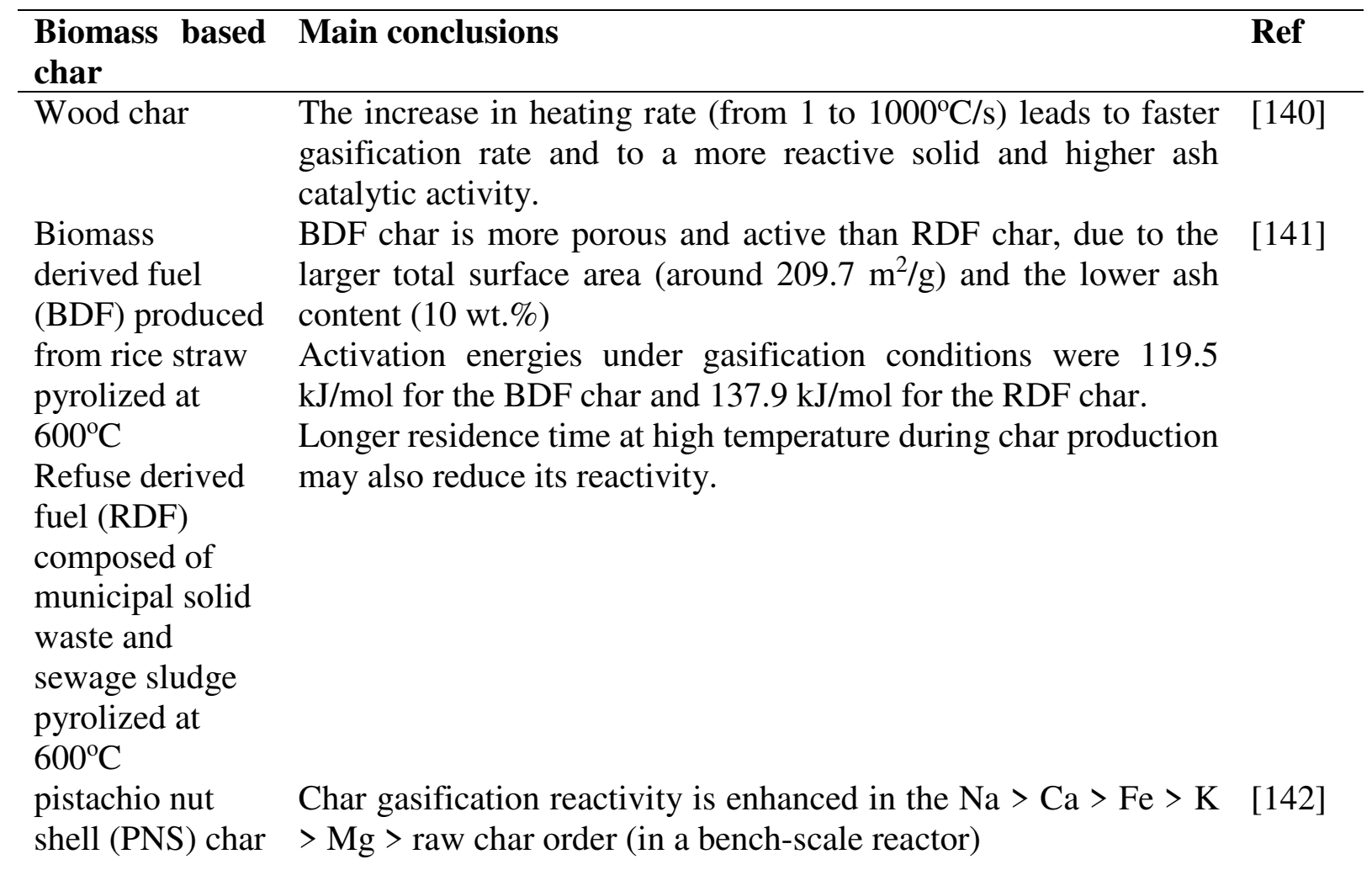


wood char

Steam-gasification: 2-5 faster than $\mathrm{CO}_{2}$ - gasification and gives a [143] higher calorific value of the produced syngas.

RDF-derived Reactivity is increased by enhancing the partial pressure of steam [144]

char from 0.333 to $0.667 \mathrm{bar}$, at $850^{\circ} \mathrm{C}$

pure corn stover The reactivity to $\mathrm{CO}_{2}$ is affected by temperature and content of

char

$\mathrm{CO}_{2}$. Char conversion rates increases by increasing the temperature and the $\mathrm{CO}_{2}$ concentration.

\subsubsection{Gasification reactors and applications}

The reactors adapted to the gasification of chars can be classified into 5 main categories (Figure

6), with specific range of operation conditions:

- Fixed/moving bed (updraft, downdraft and cross-draft bed)

- Fluidized bed (bubbling, circulating)

- Entrained flow

- $\quad$ Rotary kiln

- Plasma gasifier 


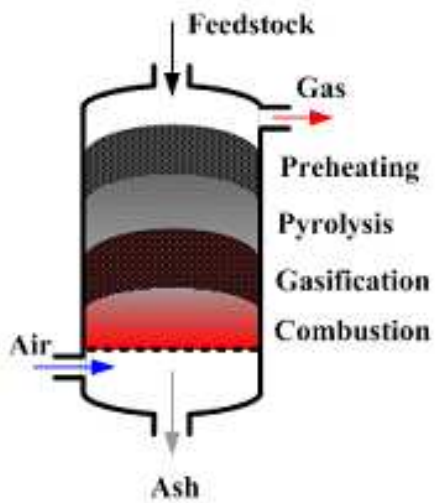

Moving bed gasifier


Fluidized bed gasifier Entrained flow gasifier

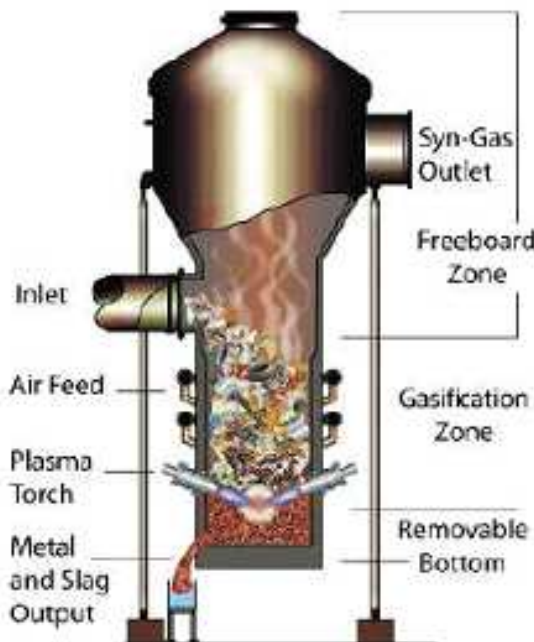

Plasma gasifier

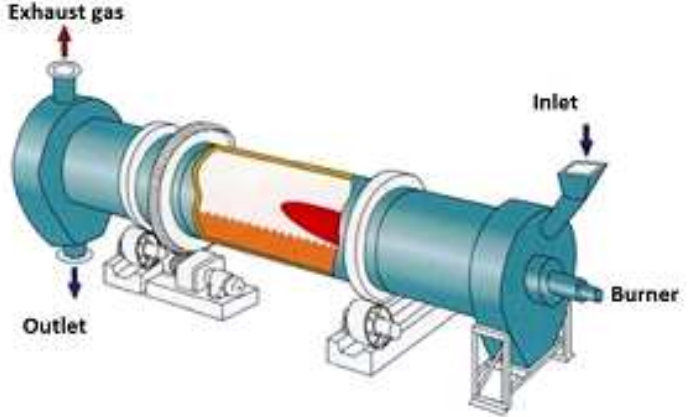

Rotary kiln gasifier 


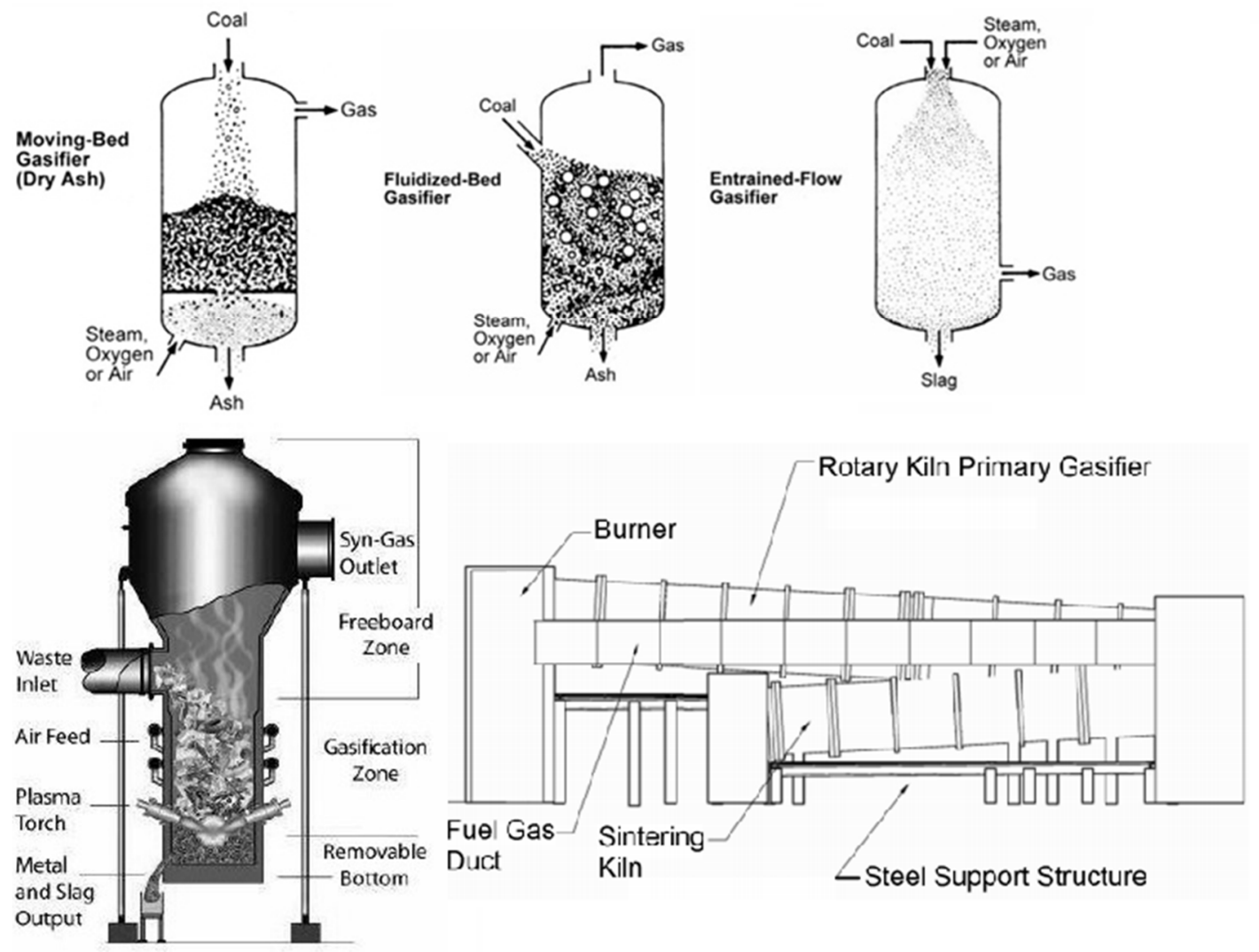

Figure 6. Types of char gasifiers (adapted from [146] and [147])

Such technologies allow to capitalize the use of biomass derived carbon materials. For example, a power plant of $4800 \mathrm{~kW}$ electricity generation power, based on wood char gasification technology (temperature range $900-1000{ }^{\circ} \mathrm{C}$ ), was built in the framework of a sawmill project at Guyana; the objective was to satisfy the power requirements of a sawmill industry (located at Mabura Hill), and the nearby township [148]. Another similar plant was also implemented in Chacco (Paraguay). The capital cost of such power plants was about 15-20\% lower than that of a steam power generation plant.

Pellets of corn cobs chars were co-fired with coal in a 17-megawatt Willmar municipal power plant (by Chippewa Valley Ethanol Company) in Benson with the help of the Agricultural Utilization Research Institute in Minnesota (USA). This procedure succeeded to decrease the power plant emissions and to reach the new emission limits directives [149]. 
Small updraft and downdraft gasifiers, able to utilize biomass derived char as fuel to operate vehicles, boats, trains, and small electric generators, were developed during the second World War. These gasifiers can also be coupled with diesel engines to produce electricity. The replacement of up to $70 \%$ of the petroleum derived fuels with syngas, for operating stationary engines, is a worthwhile investment, especially for isolated areas [150].

Transforming char into fuel gas has been also successfully tested on a pilot scale entrained-flow gasifier by Suncoal Industries $\mathrm{GmbH}$, in cooperation with the Technical University of Munich (Germany), in 2017. Landscape management waste products, garden waste and other similar materials from agriculture, horticulture and food production, were at first converted into char and then into a fuel gas for feeding an engine combining a heat and a power unit [151].

Chemical looping gasification is a promising new technology that can produce high quality and low cost syngas. The economic gain is in particular due to the possibility to avoid the use of pure oxygen and to the limited use of high temperature steam. As a reference, the works of Huang et al. (2017) have to be cited; the authors enhanced biomass char conversion by using a highly active $\mathrm{Fe}-\mathrm{Ni}$ bimetallic oxide $\left(\mathrm{NiFe}_{2} \mathrm{O}_{4}\right)$, as oxygen carrier. The thermodynamic calculations predicted that the gasification efficiency of the biomass derived char might attain the maximum value at $\mathrm{OC} /$ char molar ratio of 0.3 [148]. Using the same technology, $\mathrm{CO}_{2-}$ gasification of char in presence of oxygen carriers significantly increased the conversion rate that was proved to be governed by mass transfer, rather than by kinetic limitations [149].

\subsubsection{Gasification performance and emissions}

In order to evaluate the performance and the efficiency of gasification systems, the following parameters are commonly used $[152,153]$ :

- Cold gas efficiency CGE $=\frac{\mathrm{m}_{\text {syngas }} \times \mathrm{LHV}_{\text {syngas }}}{\mathrm{m}_{\text {fuel }} \times \mathrm{LHV}_{\text {fuel }}} \times 100 \%$, 
- Hot gas efficiency HGE $=\frac{\mathrm{m}_{\text {syngas }} \times \mathrm{LHV}_{\text {syngas }}+\mathrm{m}_{\text {syngas }} \mathrm{c}_{\mathrm{p}}\left(\mathrm{T}_{\mathrm{f}}-\mathrm{T}_{0}\right)}{\mathrm{m}_{\text {fuel }} \times \mathrm{LHV}_{\text {fuel }}} \times 100 \%$,

- Carbon Conversion Efficiency

$\mathrm{CCE}(\%)=12 \times \mathrm{Y}_{\text {dry gas }} \times\left\{\frac{\left[\mathrm{CO}+\mathrm{CO}_{2}+\mathrm{CH}_{4}\right]+2 \times\left[\mathrm{C}_{2} \mathrm{H}_{2}+\mathrm{C}_{2} \mathrm{H}_{4}+\mathrm{C}_{2} \mathrm{H}_{6}\right]}{22.4 \times \mathrm{C}}\right\} \times 100 \%$

- Energy Conversion Efficiency ECE $=\frac{\mathrm{m}_{\text {syngas }} \times \mathrm{LHV}_{\text {syngas }}}{\mathrm{P}_{\text {plasma }}+\mathrm{m}_{\text {fuel }} \times \mathrm{LHV}_{\text {fuel }}} \times 100 \%$,

-Specific Energy Requirements

$\mathrm{SER}=\frac{\mathrm{P}_{\text {plasma }}}{\mathrm{m}_{\text {syngas }} \times \mathrm{M}_{\text {syngas }}},[\mathrm{kJ} / \mathrm{mol}$ or $\mathrm{kJ} / \mathrm{kg}$ or $\mathrm{kWh} / \mathrm{kg}]$,

Where

$\mathrm{m}_{\text {syngas }}$, mass flow rate of syngas ( $\left.\mathrm{mol} / \mathrm{s}\right)$,

$\mathrm{M}_{\text {syngas, }}$ molar mass of syngas $(\mathrm{kg} / \mathrm{mol})$.

$\mathrm{m}_{\text {syngas }}$ and $\mathrm{m}_{\text {fue }}$, mass flow rates of product gas and feedstock $\left(\mathrm{kg}\right.$ or $\left.\mathrm{Nm}^{3}\right)$

$\mathrm{LHV}_{\text {syngas }}$ and $\mathrm{LHY}$, net calorific values of product gas and feedstock $\left(\mathrm{MJ} / \mathrm{kg}\right.$ or $\left.\mathrm{MJ} / \mathrm{Nm}^{3}\right)$

$\mathrm{Y}_{\text {drygas }}$, dry gas yield in $\mathrm{Nm}^{3}$ per $\mathrm{kg}$ of dry feedstock $\left(\mathrm{Nm}^{3} / \mathrm{kg}\right)$

$\mathrm{c}_{\mathrm{p}}$, the specific heat capacity $(\mathrm{J} / \mathrm{kg} \mathrm{K})$,

$\mathrm{T}_{\mathrm{f}}$, the temperature at the gasifier exit $(\mathrm{K})$

$\mathrm{T}_{0}$, the temperature of the fuel (feedstock) entering the gasifier (K)

P, plasma torch power (W).

The value of CCE gives an indication of the amount of unconverted material, thus providing a measure of the chemical efficiency of the process. ECE is very similar to the CGE, but includes external energy input (all thermal process). In the case of plasma application, SER is the ratio between the input electrical power, used by plasma, and the amount of the produced syngas. 
A drawback in the application of gasification are certain negative effects towards environment and human health, such as the release of dust, biomass ash, fly ash/char and hazardous gases. On the other hand, gasification presents environmental and social benefits as enlightened by Evangelisti et al. (2015). The authors showed the lower environmental impact of gasification, when compared to conventional municipal solid waste char treatment technologies, in terms of carbon footprint, global warming, acidification, eutrophication, photochemical ozone creation, and human toxicity potentials [152]. Indeed, by applying gasification technologies, $\mathrm{SO}_{2}$ emissions were divided by 4 and NOx reduced of 33\%. Watson et al. (2018) reported that particulate matter (PM2.5) emissions were 3 times lower for gasification than for combustion, particularly due to the lower NOx emissions. NOx emission were respectively of 0.05 and 0.15 kg PM2.5 eq. for a moving-grate combustor and a gasifier [153].

\subsubsection{Barriers to gasification applications}

Char gasification systems present various problems as the release of hot gases, that are usually out-streamed with dust, and that contain up to $1 \mathrm{wt}$. \% of tar and particulates (mainly produced by downdraft gasifiers). If the dust is not properly removed, costly problems, connected to maintenance and reliability, can occur. The improper removal of these syngas contaminants is the main cause of gasifier engine system failure. The gas is very dirty during the system startingup and must be burned in the gasifier until the system reaches the stationarity.

\subsection{Chars based catalyst for syngas and hydrogen production}

\subsubsection{Tar reforming/cracking for syngas production}


Catalytic tar reforming is a process used to transform the complex hydrocarbon mixture, deriving from gasification and pyrolysis, into syngas. Once purified, syngas can be used as feedstock in a large variety of reactions to produce chemicals and building blocks.

Expensive catalysts such as zeolites, transition-metal, and alkali-metal based materials are usually used for this process [154], but, recently, biomass derived chars have been taken into consideration due to their high surface area, and their relatively high minerals and metals contain (catalytically active), that are generally well dispersed on the char surface [155]. Structure and morphology also contribute to the reforming catalytic activity of chars. The catalytic behavior of various chars was then related to the presence of weak bonds and of structural defects in the char's structure that can act as catalytic active sites [156].

Biomass derived chars can also be used as catalysts' support. Syed-Hassan et al. (2016), for example, deposited cobalt and nickel on char in order to obtain active catalysts in toluene reforming [157].

Another interesting point for using chars as catalyst or catalyst support is the fact that they can be produced directly in the gasifier. In this configuration, the deactivation is not anymore a concern, since the deactivated char can be easily replaced by fresh char produced inside the reactor (Figure 7) [158-160]. Besides, they can easily be reused for several runs without significant loss of activity. Tar valorization can also be performed on chars based catalysts issued from adsorption processes of pollutants [161]. In this approach, chars were firstly saturated of heavy metals and then used as char-supported metallic catalysts, for tar conversion. 

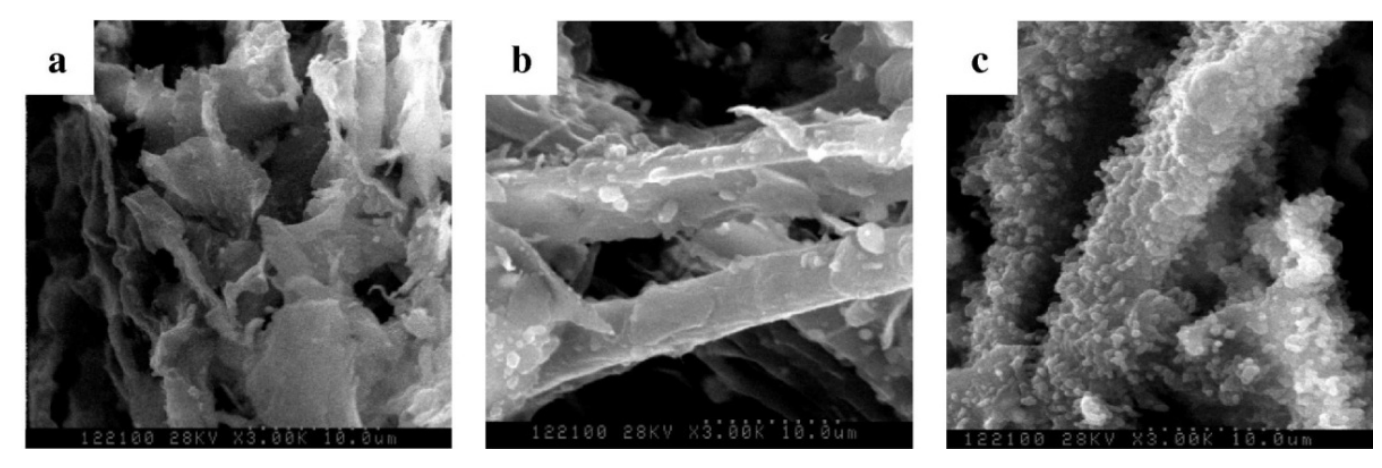

Figure 7. SEM images of char after the experiment at $700{ }^{\circ} \mathrm{C}$ under microwave heating. (a) Fresh char; (b) char from toluene reforming; (c) char from toluene cracking) (Reproduced with permission from [159]).

Several researches, reported in the literature, show the high potential of bare chars in tar reforming [157, 162]. Klinghoffer et al. (2015) for example, investigated the influence of the minerals content and inorganics distribution on the char catalytic activity [155]. In another work, Zhang et al. [163] produced chars by pyrolysis of mallee wood and compared the performances of unwashed and acid washed chars, showing, for both samples, a good activity in tar reforming, even if a slighter higher activity for the unwashed catalyst was measured. Syed et al. (2016) prepared char-supported nickel and cobalt catalysts tested in the steam reforming of toluene, used as tar model molecule [157]. The char precursor was constituted of palm kernel shell and its stability was shown to be good up to $850{ }^{\circ} \mathrm{C}$, temperature at which the agglomeration of the metal particles, the loss of alkali and alkaline earth metal, and the coke deposition take part. Shen et al. (2014) performed in-situ tar conversion with very high tar conversion (about 93\%), during gasification by using a rice husk char as support for nickel and iron species [162].

Although biomass derived chars as catalytic materials showed good performances, their relative low activity and mechanical resistance, compared to conventional catalysts, still restrain their application panel. Indeed, the relocation and agglomerations of metal and inorganic species, 
dispersed in the biomass derived chars, and the coke deposition, during the reforming process, cause the poisoning of the catalyst active sites, the blocking of the char pores, and the decreasing of the surface, thus lowering the catalytic activity $[157,162,164,165]$. During reforming, chars can lose oxygenated species due to ring condensation, consequently inorganics and metals can be displaced in the char structure and agglomerate [165].

\subsubsection{Hydrocarbons/oils reforming (hydrogen production)}

Biomass derived chars can be also valorized in the production of hydrogen, a very promising and sustainable alternative to fossil fuels, as energy vector. Hydrogen can be obtained by further reforming of the liquid and gaseous phases produced during the pyrolysis, gasification, and tar reforming processes.

High hydrogen yields, of around $89 \%$, were obtained by bio-oil steam-reforming, using alkaliand alkaline metallic-rich chars as catalyst (Figure 8) [166]. A hydrochar issued from a macroalgae; was used as catalyst in the hydrothermal gasification of the same substrate (the Clodophora glomerata) in order to enrich with hydrogen the gas phase [167]. Various chars, deriving from different biomass sources, have been used as catalyst supports, to prepared Nibased catalysts [168]. Those prepared on cotton-derived char, presented the highest hydrogen yield (64 \% $\mathrm{H}_{2}$ in the gas phase), while rice-derived chars showed lower performances. 


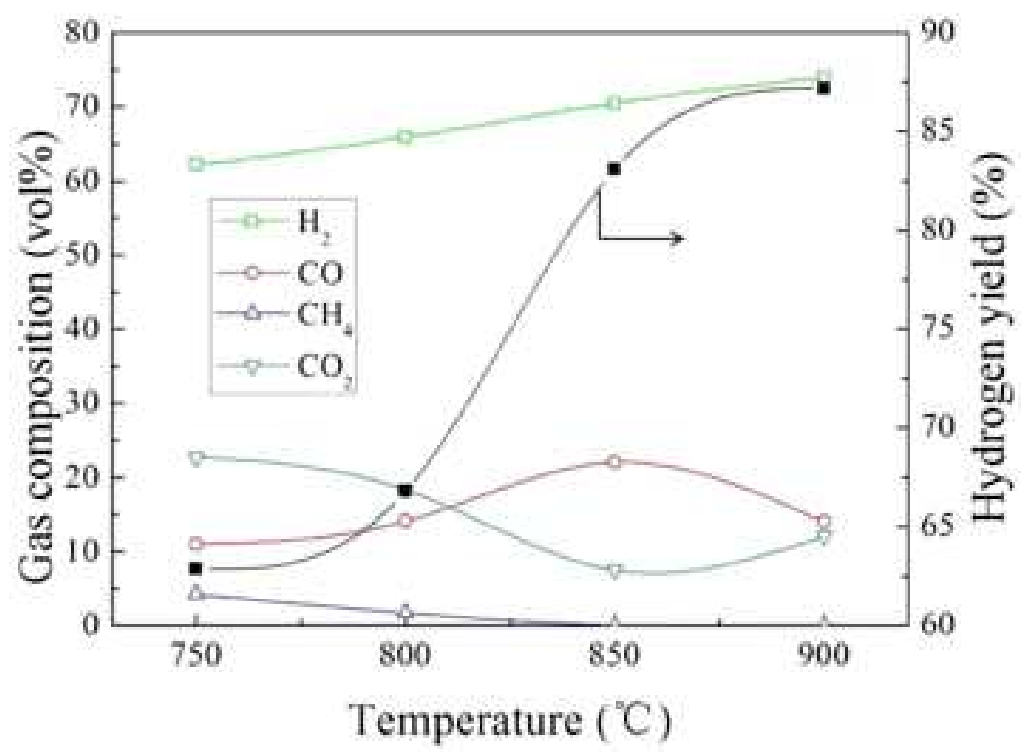

Figure 8. Effect of temperature on hydrogen yield from wheat straw char gasification (Reproduced with permission from [166])

\section{Energy storage using biomass based chars}

Even though the use of renewable energy sources is an up-to-the-minute solution, security and supply uncertainties, related to their intermittent character, still remain open issues. Storage systems are the solution to these concerns. Whether it is converted, harvested or produced, energy accumulation and supply must be technically and economically feasible and viable.

This section is focused on energy storage systems applying chars and/or activated carbons as adsorbents or electrodes. Among the possible storage systems, gas storage systems (hydrogen and methane) and electrochemical storage devices (supercapacitors, fuel cells and batteries), are here presented.

\subsection{Gas storage by biomass derived chars}

Methane and hydrogen are among the cleanest gaseous fuels. Currently, their storage methods are costly and risky. Indeed, the storage of $\mathrm{H}_{2}$ and $\mathrm{CH}_{4}$ in liquid state requires cryogenic devices, 
and special tanks and pressurized bottles (700 bars), that requires very expensive compression processes, are needed for the storage in gas phase [169].

Storage at low pressure and normal temperature in a solid matrix can be a good alternative, but only if the material presents high volumetric storage density. High specific surface area, high porous volume, tunable pore size distribution, as well as variability in the surface chemistry, are also desired features for gas storage applications.

Several biomass precursors have been explored (Table 8), but simple pyrolysis of biomass does not provide carbon materials with surface area higher enough and, in most part of the cases, an activation step is requested in order to develop the porosity. Activated chars are usually preferred over zeolites, - and carbon nanotubes in industry, due to their simple synthesis, the possibility of tailoring the pore distribution and to perform chemical functionalization, as well as for their low cost (if produced starting from biomass) [170]. Mainly two types of activation procedures are used: the physical activation by $\mathrm{CO}_{2}$ or water steam, and the chemical activation by $\mathrm{KOH}, \mathrm{H}_{3} \mathrm{PO}_{4}$, etc. The adsorption isotherms of methane of activated carbons prepared by modification of chars issued from sustainable biomass are reported in Figure 9 [171].
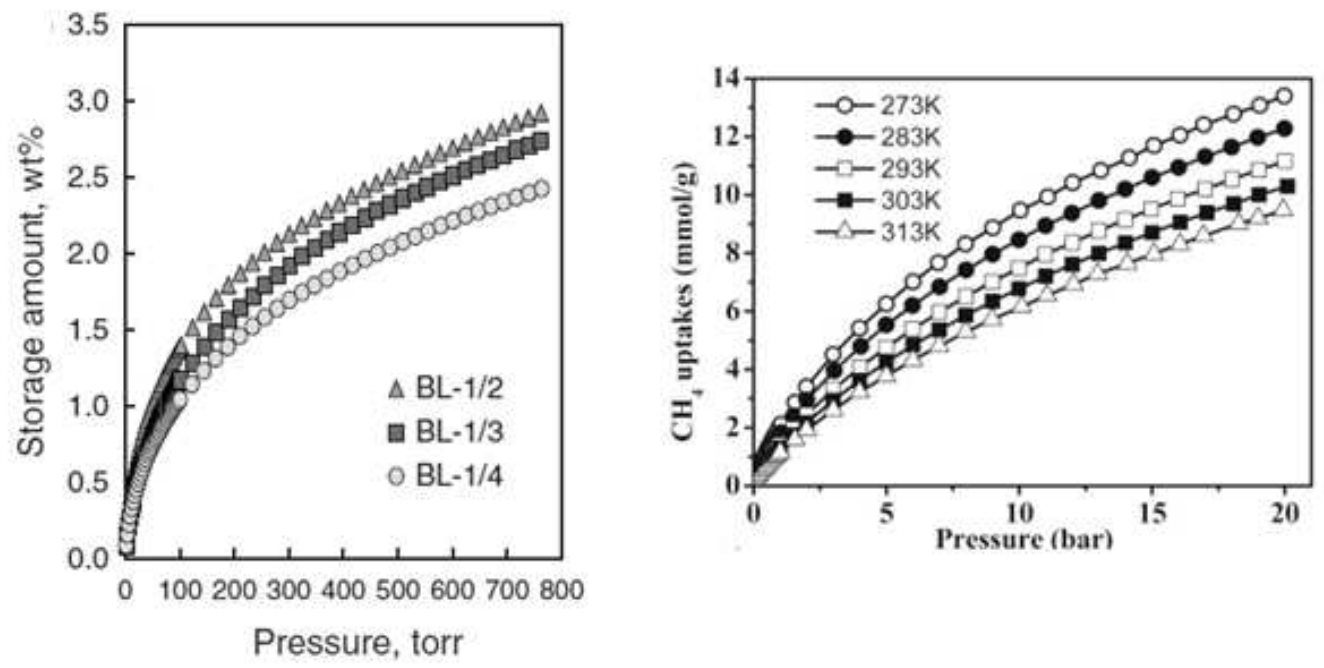


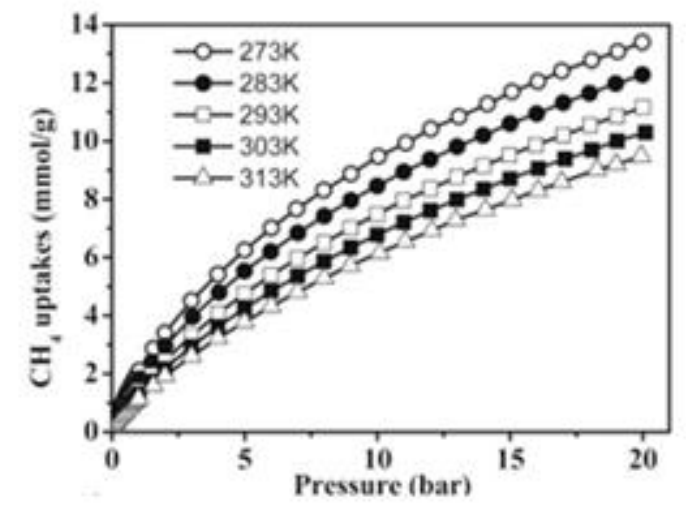

Figure 9. $\mathrm{CH}_{4}$ adsorption isotherms on starch chars $\left(\mathrm{CO}_{2}\right.$-activated at different temperatures)

(Reproduced with permission from [171]).

It is generally accepted that an efficient adsorbent for the storage of methane must have a high specific surface area (from 1000 up to $3000 \mathrm{~m}^{2} / \mathrm{g}$ ), and a pore size distribution in the 1 to $2 \mathrm{~nm}$ range, with a micropore volume of at least $85 \%$ of the total pore volume.

Examples of precursor materials used to obtain the required characteristics are rubber seed coats, olive stones, coconut shell, oil palm fiber, almond shells, sugarcane molasses, and corncobs [172]. Activated carbons can be optimized for methane storage by testing several activation conditions (Table 8).

Table 8. Biomass based activated carbons for methane storage

\begin{tabular}{lll}
\hline Adsorbent & Optimal activation conditions & Ref \\
\hline $\begin{array}{l}\text { Corn cobs } \\
\text { based AC }\end{array}$ & $\begin{array}{l}\text { Activation of temperature } 550^{\circ} \mathrm{C} \text { for } 60 \text { minutes and impregnation } \\
\text { with } \mathrm{KOH} / \mathrm{char} \text { at } 1: 1 \text { ratio }: \text { methane adsorption capacity increased } \\
\text { from } 25 \mathrm{v} / \mathrm{v} \text { to up to } 120 \mathrm{v} / \mathrm{v} \text { at } 25^{\circ} \mathrm{C} \text { and } 3.44 \mathrm{MPa}\end{array}$ \\
$\begin{array}{lll}\text { Cellulose } \\
\text { based AC }\end{array}$ & $\begin{array}{ll}\text { 150 v/v at } 298 \mathrm{~K} \text { and } 3.5 \mathrm{MPa} \\
\text { Candied } \\
\text { chestnut } \\
\text { industry }\end{array}$ & $\begin{array}{l}\text { Best methane storage capacities for the samples with high BET } \\
\text { surface area. }\end{array}$ \\
& $\begin{array}{l}\text { Physical activation methods: a higher activation degree resulted in a } \\
\text { development of the porosity thus resulting in a higher surface area. }\end{array}$
\end{tabular}


waste based Chemical activation: low activation temperature $\left(700-800{ }^{\circ} \mathrm{C}\right)$ and $\mathrm{AC} \quad$ high activation ratio/precursor: higher amount of narrow micropores $(<0.8 \mathrm{~nm})$

Synthetic AC Simulation prediction: maximum storage capacity of AC $209 \mathrm{v} / \mathrm{v}$ at [176] 3.4 MPa

For $\mathrm{H}_{2}$ storage targets, parameters, such as the carbon precursor type, the activation agent type and amount, the activation temperature and time, are varied to design efficient adsorbents (Table 9). Chemical activation with $\mathrm{KOH}$ is the most used methodology since it produces highly microporous activated carbons with well-developed surface areas (up to $3700 \mathrm{~m}^{2} / \mathrm{g}$ [173]), in shorter time and at lower activation temperatures than those used in physical activation processes. However, as negative point, the treatment with $\mathrm{KOH}$ requires a supplementary washing step, in order to remove the impurities introduced during the activation process.

Table 9. Hydrogen storage by biomass based chars

\begin{tabular}{|c|c|c|c|c|}
\hline Precursor-Activating agent-T(K)-(bar) & $\begin{array}{c}\text { SSA } \\
\left(\mathbf{m}^{2} / \mathbf{g}\right)\end{array}$ & $\begin{array}{c}\mathrm{V} \mu \\
\left(\mathrm{cm}^{3} / \mathrm{g}\right)\end{array}$ & $\begin{array}{c}\mathbf{H}_{2} \text { capacity } \\
\text { storage }(\mathbf{w t} \%)\end{array}$ & Ref \\
\hline Cellulose-KOH-298K-20bars & 3771 & - & 0.5 & [177] \\
\hline Olive pomace-KOH-298K-204bars & 1269 & 0.48 & 1.22 & [178] \\
\hline Jute fibers-KOH-303K-40bars & 1224 & 0.43 & 1.2 & [179] \\
\hline Tamarind seeds-KOH-303-60bars & 1784 & 0.64 & 1.36 & [180] \\
\hline Coffee shell-KOH-298K-140bars & 3149 & - & 0.91 & [181] \\
\hline Olive bagasse- $\mathrm{CO}_{2}-298 \mathrm{~K}-200 \mathrm{bars}$ & 1185 & 0.45 & 0.63 & [182] \\
\hline Fruit bunch- $\mathrm{CO}_{2}-77 \mathrm{~K}-1 \mathrm{bar}$ & 687 & 0.297 & 1.97 & [183] \\
\hline Beer lees-KOH-77K-1bar & 1927 & 0.70 & 2.92 & [184] \\
\hline Rice husks-KOH-77K-1bar & 2682 & 0.792 & 2.85 & [178] \\
\hline Cellulose-KOH-77K-1bar & 3771 & - & 3.9 & [185] \\
\hline Starch-CO ${ }_{2}-77 \mathrm{~K}-1 \mathrm{bar}$ & 3281 & 1.1 & 2.3 & [171] \\
\hline Fungi-KOH-77K-1bar & 2137 & 0.87 & 2.4 & [186] \\
\hline Corncob-KOH-77K-1bar & 3708 & 1.14 & 3.2 & [187] \\
\hline Chitosan-KOH-77K-1bar & 2919 & 1.19 & 2.71 & [188] \\
\hline Hemp Stem-KOH-77K-1bar & 3078 & 1.13 & 3.18 & [189] \\
\hline Corncob-KOH-77K-40bars & 3708 & 0.59 & 5.80 & [190] \\
\hline Cellulose-KOH-77K-20bars & 3771 & - & 8.1 & [177] \\
\hline Olive pomace-KOH-77K-25bars & 1269 & 0.48 & 3 & [191] \\
\hline Olive pomace-KOH-77K-209bars & & & 6.11 & \\
\hline Activated Carbon-KOH-77K-20bars & 3190 & 1.09 & 7.08 & [190] \\
\hline
\end{tabular}




\begin{tabular}{lcccc} 
Olive bagasse-CO 2 -77K-25bars & 1185 & 0.45 & 2.59 & {$[182]$} \\
Starch-CO 2 -77K-20bars & 3281 & 1.1 & 6.9 & {$[171]$} \\
Fungi-KOH-77K-20bars & 2137 & 0.87 & 5.0 & {$[186]$} \\
Corncob-KOH-77K-20bars & 3708 & 1.14 & 5.5 & {$[187]$} \\
Chitosan-KOH-77K-40bars & 2840 & 1.06 & 5.01 & {$[188]$} \\
Chitosan-KOH-77K-20bars & 2919 & 1.19 & 6.77 & \\
Melaleuca bark-KOH-77K-10bars & 3170 & 1.07 & 3.18 & {$[192]$} \\
\hline
\end{tabular}

By analyzing table 9, it can be noticed that, at room temperature, the hydrogen adsorption capacity is very low (the maximum achieved capacity at room temperature and high pressure is only slightly higher than $1 \mathrm{wt} \%$, even when the surface area of the carbon is very high $(\sim 3000$ $\left.\mathrm{m}^{2} / \mathrm{g}\right)$ ). Storage devices working at cryogenic conditions and high pressure (20 - 209 bars) gave better results, in term of storage capacity (up to $8.1 \mathrm{wt} . \%$ ), than storage devices working at atmospheric pressure. Further investigations brought to the conclusion that the $\mathrm{H}_{2}$ storage capacity is more clearly correlated to the presence of ultra-micropore volume (volume of pore with size $<0.7 \mathrm{~nm})$ than to the surface area of carbon materials $[114,115]$. Nevertheless, solutions requiring low temperatures and high pressures cannot be yet applied due to the high costs, when compared to the current available technologies.

\subsection{Electrochemical storage by biomass derived chars}

The use of different energy storage devices in specific applications is connected to the type of the constituent material of the electrode, generally carbon materials. Carbon electrodes present a high added value (selling price from US $\$ 1500$ to US $\$ 5000$ per ton), especially for those used in electric arc furnaces for aluminum production and metal recycling [132].

The use of biomass-derived carbon materials, as electrodes for energy storage devices, is increasing, and many efforts are made in order to improve their specific surface area, their electric and ionic conductivity, as well as their mechanical and chemical stability. Capacitors, batteries (lithium-sulfur; lithium-ion and sodium-ion batteries), fuel cells, etc. may all respond positively to the need of electrochemical energy storage development (Figure 10). 


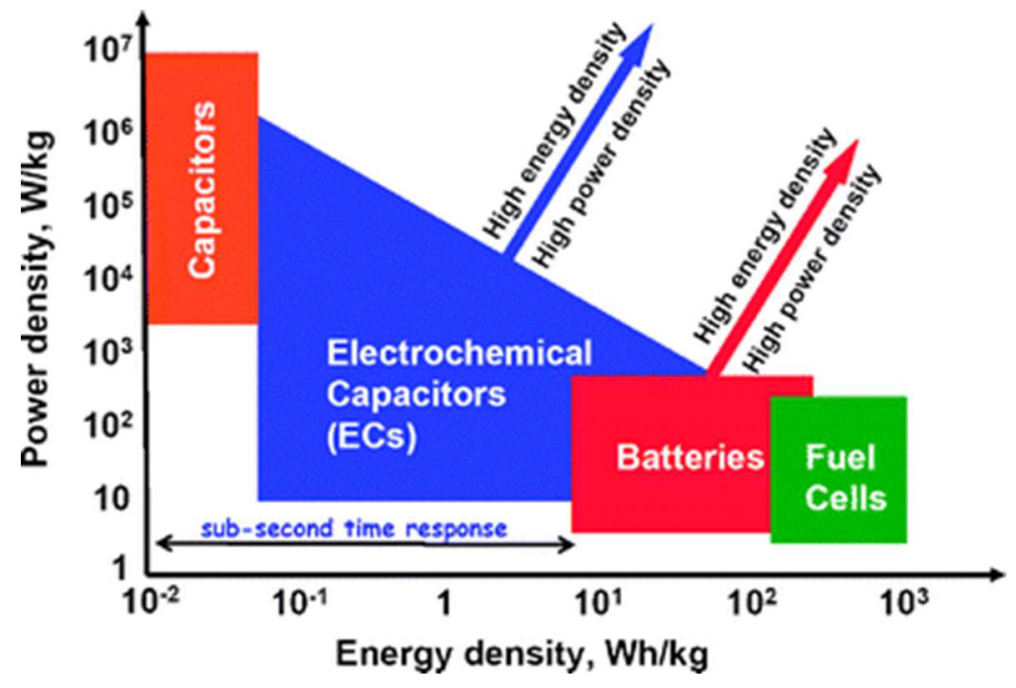

Figure 10. Common energy storage devices [193] (Reproduced by permission of The Royal Society of Chemistry)

\subsubsection{Supercapacitors}

Supercapacitors, also known as electrochemical capacitors or electric double-layer capacitors, are energy storage devices exploiting charge accumulation in the electric double-layer. They can be used as continuous power sources in electric vehicles, digital communication systems, etc. They are different from batteries because the charge is stored in a physical manner, thus limiting the energy density (few $\mathrm{Wh} / \mathrm{kg}$ ). However, the lack of electrochemical reactions ensures very high power density, quick charge/discharge capability, and long cycle life.

Activated carbons are ideal candidates as electrode material for supercapacitors. Different kinds of biomass can be used as precursors for carbon (Table 10), provided that their carbon matrix is microporous $(<2 \mathrm{~nm})$ and mesoporous $(2-50 \mathrm{~nm})$ at the same time. Indeed, mesopores facilitate mobility of electrolyte ions, while micropores store the transferred charge. 
Table 10. Supercapacitors performance of electrodes made from various biomass-based char precursors

\begin{tabular}{|c|c|c|c|}
\hline $\begin{array}{c}\text { AC (biomass char-activation agent-activation } \\
\text { temperature) }\end{array}$ & $\begin{array}{c}\text { SSA } \\
(\mathrm{m} 2 / \mathrm{g})\end{array}$ & $\begin{array}{c}\text { Capacitance } \\
(\mathbf{F} / \mathbf{g})\end{array}$ & Ref \\
\hline Waste coffee beans- $\mathrm{ZnCl} 2-900{ }^{\circ} \mathrm{C}$ & 1019 & 368 & {$[194]$} \\
\hline Sunflower seed shell-KOH- $800{ }^{\circ} \mathrm{C}$ & 2509 & 311 & [195] \\
\hline Banana fibers- $\mathrm{ZnCl} 2-800^{\circ} \mathrm{C}$ & 1097 & 74 & [196] \\
\hline Sugarcane bagasse- $\mathrm{ZnCl} 2-900{ }^{\circ} \mathrm{C}$ & 1788 & 300 & [197] \\
\hline Coffee shells-ZnCl2-900 ${ }^{\circ} \mathrm{C}$ & 842 & 158 & [198] \\
\hline \multirow{2}{*}{ Neem dead leaves,-,- } & 1230 & 400 & [199] \\
\hline & 3404 & 273 & \\
\hline Corn grains,-,- & 3420 & 257 & {$[200]$} \\
\hline oil palm fruit bunches,-,- & 1656 & 111 & [201] \\
\hline Sorghum pith-NaOH- & 35 & 320 & [202] \\
\hline Cotton stalk-H3PO4-800 ${ }^{\circ} \mathrm{C}$ & 1481 & 114 & [203] \\
\hline Coconut kernel-KOH-600 ${ }^{\circ} \mathrm{C}$ & 1200 & 173 & [204] \\
\hline Rice husk-ZnCl2,- & 1442 & 243 & [205] \\
\hline Bamboo-Steam- $800{ }^{\circ} \mathrm{C}$ & 1532 & 228 & [206] \\
\hline Recycled paper-KOH,- & 416 & 180 & [207] \\
\hline Coconut shell-Steam $-800^{\circ} \mathrm{C}$ & 1532 & 228 & [208] \\
\hline Pistachio shells-KOH/CO2-780 ${ }^{\circ} \mathrm{C}$ & 2145 & 122 & [209] \\
\hline Waste tea leaves-KOH,- & 2841 & 350 & [210] \\
\hline Water hyacinth-KOH/microwave assisted,- & 1010 & 179.6 & [211] \\
\hline Water hyacinth- $\mathrm{ZnCl} 2,-$ & 579.94 & 472 & [212] \\
\hline Water hyacinth-KOH- $800{ }^{\circ} \mathrm{C}$ & 1308 & 273 & [213] \\
\hline Celtuce leaves-KOH,- & 3400 & 273 & [204] \\
\hline Tobacco stem-KOH,- & 3326.7 & 190 & {$[202]$} \\
\hline Tobacco rods-KOH- $800{ }^{\circ} \mathrm{C}$ & - & 286.6 & [214] \\
\hline Hemp back-KOH-800 ${ }^{\circ} \mathrm{C}$ & 2287 & 106 & [215] \\
\hline Argan seed shells-KOH,- & 2100 & 335 & [216] \\
\hline Brussel sprouts- $\mathrm{KOH}-800{ }^{\circ} \mathrm{C}$ & 2410 & 255 & [217] \\
\hline Flax textiles-MnO2,- & 683.73 & 46.54 & [218] \\
\hline Kenaf stem-MnO2,- & 416 & 17.3 & [219] \\
\hline Mollusc shell,-,- & 1696 & 8.47 & {$[220]$} \\
\hline
\end{tabular}

Although activated carbons are well established in supercapacitors industry, the limit for further improvement as material in the energy accumulators' field is probably attained. In fact, their performance is hindered by the dominance of micropores that slow-down the diffusion of the electrolyte ions. Besides, their preparation is very complex (setting and monitoring of equipment, ...), costly (need of high temperature steam, expensive chemicals, ...) and hazardous (use of metal chloride salts, ... ). For this reason, the optimization of the preparation 
processes of biomass-derived carbon materials, that could substitute the traditional carbons as effective electro-active materials, remains an open issue.

\subsubsection{Batteries}

Batteries (Lithium - Sulfur; Lithium - ion; Sodium - ion) are well-known energy-storage devices, in particular thanks to their high energy densities. However, each of these batteries present some limitations that can be overcome by substituting them with biomass derived chars. For example, the low electrical conductivity of sulfur in Li-S batteries is the cause of low cycling stability. It has been demonstrated that incorporating sulfur into different biomass based carbon matrixes could not only improve the conductivity of the sulfur species, but also accommodate the volume expansion of sulfur during cycling [221-224].

As another example, graphite in $\mathrm{Li}-\mathrm{i}$ ion and $\mathrm{Na}$-ion batteries present low capacity and cycling rate, that are not compatible with the use in power advanced systems, such as electric or hybrid vehicles. Anodes technology is demanding of novel hard carbonaceous materials, and biomass chars can act as precursor [225-228]. In particular, biomass-derived carbons with highlydeveloped surface chemistry, and especially those containing $\mathrm{N}$-functional groups, could start the redox reactions and consequently boost the specific capacitance (of few orders of magnitude) [228]. To do this, Li et al. (2014) converted N-rich bio-precursor (chicken egg whites) into high-content functionalities and high surface area capacitor electrodes. Knowing that an activation temperature higher than $600^{\circ} \mathrm{C}$ can bring to the loss of nitrogen functionalities, the authors proposed an alternative process starting from denatured proteins, which did not require the use of templates. Low-temperature activation under argon flow produced highly microporous material (SSA and total pore volume up to $1405 \mathrm{~m}^{2} / \mathrm{g}$ and 0.73 $\mathrm{cm}^{3} / \mathrm{g}$, respectively), containing high amount of $\mathrm{N}$ - and O-functional groups. The asymmetric capacitor, assembled with this $\mathrm{AC}$ and $\mathrm{NiCo}_{2} \mathrm{O}_{4} /$ graphene positive electrode, presented higher 
energy density (48 Wh/kg) than capacitors prepared starting from commercial activated carbon $(23 \mathrm{Wh} / \mathrm{kg})[229]$.

\subsubsection{Fuel cells}

A fuel cell or Direct Carbon Fuel Cell (DCFC) is an electrochemical energy-storage device in which the chemical energy of carbon is converted to electricity by oxidizing a solid carbonaceous material into carbon dioxide. An innovative application of biomass derived char as a fuel was tested in such kind of device. Chars were integrated in Molten Carbonate Fuel Cells (MCFC) to produce electricity. The chemical energy contained in the char was directly converted to electrical output. At high temperatures, DCFC are able to transform the solid matrix of the feedstock into gases, which represents a thermodynamic advantage. The potential of coupling fuel-cell stack with biomass char was proved for power generation, particularly thanks to the high power density levels achieved on DCFC, 60 to $70 \%$ higher than that of mineral coal, under the same conditions [229].

Dudek et al. (2013) tested charcoal powder (by in-situ produced pyrolytic chars from beech wood and from Carbo medicinalis) as potential fuels for carbon fuel cell equipped with solid oxide electrolyte. The three samples presented graphite-like phases of carbon, although their structure was full of defects and contained amorphous carbon. They provided sufficiently high power density (50-100 $\left.\mathrm{mW} / \mathrm{cm}^{2}\right)$ under loading. The authors concluded that using anode materials with higher activities in $\mathrm{C}$ and $\mathrm{CO}$ oxidation than those currently used (Ni-YSZ) would improve the performance of such type of fuel cells for long duration of loading [231].

Lim et al. (2014) also found that, palm shell pyrolyzed at $750{ }^{\circ} \mathrm{C}$, with heating rate of $10^{\circ} \mathrm{C} / \mathrm{min}$ and residence time of 1 hour, yielded a highly potential char for DCFC applications [230]. Other researchers investigated biomass chars to support $\mathrm{Pt}$ or $\mathrm{Fe}$ species in proton-exchange 
membrane fuel cells (PEMFC) electrocatalysts [231], in microbial fuel cell (MFC) [232] for the oxygen reduction reaction [233], and in alcohols electro-oxidation [234].

\section{Costs analysis}

The char production performance and costs are closely related to the feedstock characteristics, conversion techniques, logistics (handling, densification, transport) and to the final use. Therefore, each combination of feedstock, conversion process, and application is a unique scenario. These singularities increase the complexity in determining the best strategy for sustainability.

In order to optimize such a strategy, studies on various combinations of biomass resources, conversion technologies, and utilization systems have been reported. Unfortunately, these studies are not very useful for financial analysis, because they deal with too small scale frameworks or they do not take into consideration the feedstock collection and pretreatment, or the char transport and utilization in large pilot facilities.

Anyway, some conclusions can be tentatively reported. For example, biomass residues, farming and agro-industrial wastes have lower financial cost, if compared to energy crops and algae, as the costs of collection are minimized, and those of water consumption, plantation, harvesting, etc. related to crops are suppressed.

Homagain et al. (2016) found that, using as feedstock forest harvest residues, saw mill residues, and underutilized trees, the 25-year average annual cost inventory of $1 \mathrm{MWh}$ pyrolysis plant (k\$ 381.5 per year) was the most expensive step of the production process, followed by storage/processing ( $\mathrm{k} \$ 237.2$ per year including pelleting). The transportation costs varied between $\$ 98000$ and 83000 per year. The average annual cost of operation from all scenarios adopted by the authors was $\mathrm{k} \$ 988.55$, with an actual value of $\mathrm{k} \$ 532.8$ [237].

As for the charring processes, gasification is probably the technique that cannot yet achieve successful commercialization due to high investing capital and operational costs of the 
gasification plants (construction sites, biomass pre-treatment units, reactors, producer gas conditioning systems, engines or gas/steam turbines, etc.).

In iron and steel industries, the development of large-scale applications, using chars as reducing agents, faces economic barriers. Indeed, the capital cost of a proposed charcoal plant was estimated to be $\$ 111$ million, with costs for pyrolysis unit (39\%), engineering and construction (21\%), storage (18\%) etc. Total operating costs were estimated to be $\$ 446$ per ton and the average charcoal cost at $\$ 243$ per ton [238].

The use of biomass char as catalyst precursor is motivated by their low cost and the easy recyclability of the supported metal. However, the development of this application is limited by relative low efficiency and low resistance to abrasion, compared with the available commercial catalysts. Moreover, the engineering of the biochar to enhance one or the other of the char properties would increase the cost.

\section{Practical implications, challenges and Recommendations}

Sustainable biomass based chars' production, trade and usage are important means for satisfying the energy demand. The use of biochars contributes also in generating income for individuals (rural), communities (in low and medium income countries), and government (through the issuance, licenses, business permits, etc.). It also saves the country foreign exchange that would otherwise be used to import fuel, even though supply chain is mostly informal [110]. Furthermore, the char production is a labor-intensive process. Indeed, people could be hired in different phases of char making, distribution, marketing and utilization, etc.

Despite of all this, only little attention has been oriented to such industry. Technological improvements in char production and their use in the energy field are in full development and may lead to modernization of this economic segment. This implies to obtain high efficiency processes with low environment impact. 
Even if the main challenges for each energy application of chars have been discussed in the related section, a global picture of the more common issues is presented as follows. One of the main drawbacks of char application in energy systems (production and storage) is the parent raw biomass supply. Biomass sources are often available in small batch spread out over a large geographical area, resulting in challenging or/and uneconomic collection systems. Besides, for financially viable operation, the feedstock should present physical and chemical properties suitable to be transformed into char (dry, unmixed, homogeneous, etc.). Non-homogeneous and humid feedstocks require appropriate technologies characterized by high capital investments. The char markets are also weakened by the lack of reliable information.

A recommendation for developing this sector is to involve the society and in particular rural communities for identifying any potential resource that can act as feedstock. Moreover, the performance of small char production systems should be improved, in particular due to their utility in the development of poor countries. These improvements will also indirectly help in establishing eco-friendlier processes. The major progress in the energetic usage of biomass based chars is related to the char engineering (by different modification methods). Finally, an information database system needs to be put in place and available to all char producers, traders, users, to develop the sector.

\section{Conclusions}

Energy scarcity, its supply uncertainties and the related environmental issues are concerns that can be solved in a sustainable way by using biomass derived chars. To evaluate the role of chars in future development in the energy field, an overview of the main research studies in the field was presented in order to identify the actual trends and highlight the future challenges.

Various observations can be pointed out from the survey carried out in this review article. 
First, char issued from biomass can be used in all industrial applications similarly to other fuel types (whether they are solid, liquid or gaseous), particularly in drying, gasification, steam and electricity generation, firing, etc. At the present, most studies are concentrated in the laboratory scale. Industrial scale production and usage of biomass chars are still in their early days and require more engineering support. Chars' modification and minimizing the processing costs are the key-points for promoting the biomass-derived chars' industry. A deep understanding of biomass based chars' properties is fundamental to produce biochars with specific features adapted to target applications.

Thanks to their high calorific values, biochars are promising energy vectors that can be used in combustion and gasification processes. Biomass-based char can be used in boilers to produce directly heat and/or steam to generate electricity; but co-firing with more conventional fuels often presents higher efficiency, than when used alone. Moreover, such a solution often decreases the initial investment, since already existing facilities are applied.

Even if the gasification technology is mastered since decades, it needs to be further developed for being implemented in more advanced applications. The energy recovery from gasification, can be in the form of heat, electricity, combustible gas, transportation fuels and chemicals. These outputs can supply small scale units at remote locations, as well as large scale plants.

The quality of the outputs products of thermal conversion processes could be enhanced by purifying the tar, the oil and the hydrocarbon by-products, by reforming or cracking, using sustainable catalyst supported on biomass derived chars.

Chars have attracted also considerable interest in many energy-related applications, such as energy storage (in supercapacitors and batteries), catalysis/electrocatalysis, absorption, and gas separation and storage, due to their abundance, chemical and thermal stability.

More precisely, biomass derived chars show good properties of energy storage thanks to developed pore structure and large specific surface area, which improves the electrode 
capacitance (up to $250 \mathrm{~F} / \mathrm{g}$ ). Their good electrical conductivity permits to achieve fast charge and discharge rates, as well as potential of about $2 \mathrm{~V}$. Their structure is stable at hightemperature and in corrosive media, and the cycles performance is good. Power density of the char-coated cathode reached $500 \mathrm{~mW} / \mathrm{m}^{2}$, comparable to that of $\mathrm{Pt} / \mathrm{C}$-coated cathode. In fuel cell systems, chars could achieve power density of about 60-70\% compared to coal-based fuel cells. In catalysis applications, char can be implemented in various processes, such as syngas reforming and conditioning, bio-oils upgrading, etc.

Finally, it is important to carry out technical and economic studies, as well as life cycle assessments, in order to compare all the techniques described in the present review article. The char production performance and costs are indeed closely related to feedstock characteristics, conversion techniques, logistics (handling, densification, transport), and to the final use. Therefore, each combination of feedstock, conversion process, application is a unique casestudy and increase the complexity of summarizing the biomass-derived char sector.

Funding: This research did not receive any specific grant from funding agencies in the public, commercial, or not-for-profit sectors.

\section{Acknowledgements}

The authors and the editors for the copyright permission of reusing figures, graphics and images in the present review.

\section{List of References}

[1] Jeffery S, Bezemer TM, Cornelissen G, Kuyper TW, Lehmann J, Mommer L, et al. The way forward in biochar research: targeting trade-offs between the potential wins. GCB Bioenergy 2015;7:1-13. 
[2] Uchimiya M, Lima IM, Thomas Klasson K, Chang S, Wartelle LH, Rodgers JE. Immobilization of heavy metal ions (CuII, CdII, NiII, and PbII) by broiler litter-derived biochars in water and soil. Journal of agricultural and food chemistry 2010;58:5538-44.

[3] Yao Y, Gao B, Inyang M, Zimmerman AR, Cao X, Pullammanappallil P, et al. Biochar derived from anaerobically digested sugar beet tailings: Characterization and phosphate removal potential. Bioresource Technology 2011;102:6273-8.

[4] Carrier M, Hardie AG, Uras Ü, Görgens J, Knoetze J. Production of char from vacuum pyrolysis of South-African sugar cane bagasse and its characterization as activated carbon and biochar. Journal of Analytical and Applied Pyrolysis 2012;96:24-32.

[5] Cao X, Ma L, Gao B, Harris W. Dairy-Manure Derived Biochar Effectively Sorbs Lead and Atrazine. Environmental Science \& Technology 2009;43:3285-91.

[6] Zhang C, Geng Z, Cai M, Zhang J, Liu X, Xin H, et al. Microstructure regulation of super activated carbon from biomass source corncob with enhanced hydrogen uptake. International Journal of Hydrogen Energy 2013;38:9243-50.

[7] González AS, Plaza MG, Rubiera F, Pevida C. Sustainable biomass-based carbon adsorbents for post-combustion CO2 capture. Chemical Engineering Journal 2013;230:456-65. [8] Malghani S, Jüschke E, Baumert J, Thuille A, Antonietti M, Trumbore S, et al. Carbon sequestration potential of hydrothermal carbonization char (hydrochar) in two contrasting soils; results of a 1-year field study. Biology and Fertility of Soils 2015;51:123-34.

[9] Joseph S, Pow D, Dawson K, Mitchell DRG, Rawal A, Hook J, et al. Feeding Biochar to Cows: An Innovative Solution for Improving Soil Fertility and Farm Productivity. Pedosphere 2015;25:666-79.

[10] Fisher EM, Dupont C, Darvell LI, Commandre JM, Saddawi A, Jones JM, et al. Combustion and gasification characteristics of chars from raw and torrefied biomass. Bioresour Technol 2012;119:157-65.

[11] Xiu S, Shahbazi A, Li R. Characterization, Modification and Application of Biochar for Energy Storage and Catalysis: A Review. Trends in Renewable Energy 2017;3:86-101.

[12] Guo J, Lua AC. Effect of Heating Temperature on the Properties of Chars and Activated Carbons Prepared From Oil Palm Stones. Journal of Thermal Analysis and Calorimetry 2000;60:417-25.

[13] Emrich W. End-Use Markets for Charcoal and Charcoal by-Products. In: Emrich W, editor. Handbook of Charcoal Making: The Traditional and Industrial Methods. Dordrecht: Springer Netherlands; 1985. p. 178-207.

[14] Khiari B, Jeguirim M. Pyrolysis of grape marc from Tunisian wine industry: Feedstock characterization, thermal degradation and kinetic analysis. Energies 2018;11.

[15] Khiari B, Marias F, Vaxelaire J, Zagrouba F. Incineration of a small particle of wet sewage sludge: A numerical comparison between two states of the surrounding atmosphere. Journal of Hazardous Materials 2007;147:871-82.

[16] Kordoghli S, Khiari B, Paraschiv M, Zagrouba F, Tazerout M. Impact of different catalysis supported by oyster shells on the pyrolysis of tyre wastes in a single and a double fixed bed reactor. Waste Management 2017;67:288-97.

[17] Kantarli IC, Kabadayi A, Ucar S, Yanik J. Conversion of poultry wastes into energy feedstocks. Waste Management 2016;56:530-9.

[18] Li J, Cao L, Yuan Y, Wang R, Wen Y, Man J. Comparative study for microcystin-LR sorption onto biochars produced from various plant- and animal-wastes at different pyrolysis temperatures: Influencing mechanisms of biochar properties. Bioresource Technology 2018;247:794-803.

[19] Wang T, Zhai Y, Zhu Y, Li C, Zeng G. A review of the hydrothermal carbonization of biomass waste for hydrochar formation: Process conditions, fundamentals, and physicochemical properties. Renewable and Sustainable Energy Reviews 2018;90:223-47. 
[20] Dong Q, Li H, Niu M, Luo C, Zhang J, Qi B, et al. Microwave pyrolysis of moso bamboo for syngas production and bio-oil upgrading over bamboo-based biochar catalyst. Bioresource Technology 2018;266:284-90.

[21] Antunes E, Jacob MV, Brodie G, Schneider PA. Microwave pyrolysis of sewage biosolids: Dielectric properties, microwave susceptor role and its impact on biochar properties. Journal of Analytical and Applied Pyrolysis 2018;129:93-100.

[22] Liew RK, Nam WL, Chong MY, Phang XY, Su MH, Yek PNY, et al. Oil palm waste: An abundant and promising feedstock for microwave pyrolysis conversion into good quality biochar with potential multi-applications. Process Safety and Environmental Protection 2018;115:57-69.

[23] Mao X, Kang Q, Liu Y, Siyal AA, Ao W, Ran C, et al. Microwave-assisted pyrolysis of furfural residue in a continuously operated auger reactor: Biochar characterization and analysis. Energy 2019;168:573-84.

[24] Roberts KG, Gloy BA, Joseph S, Scott NR, Lehmann J. Life Cycle Assessment of Biochar Systems: Estimating the Energetic, Economic, and Climate Change Potential. Environ Sci Technol 2010;44:827-33.

[25] Wang B, Gao B, Fang J. Recent advances in engineered biochar productions and applications. Critical Reviews in Environmental Science and Technology 2017;47:2158-207.

[26] Mullen CA, Boateng AA, Goldberg NM, Lima IM, Laird DA, Hicks KB. Bio-oil and biochar production from corn cobs and stover by fast pyrolysis. Biomass and Bioenergy 2010;34:67-74.

[27] Özçimen D, Ersoy-Meriçboyu A. Characterization of biochar and bio-oil samples obtained from carbonization of various biomass materials. Renewable Energy 2010;35:1319-24.

[28] Nogueira Junior E, Kumar M, Pankratz S, Oyedun AO, Kumar A. Development of life cycle water footprints for the production of fuels and chemicals from algae biomass. Water Research 2018;140:311-22.

[29] Liu Z, Zhang F, Liu H, Ba F, Yan S, Hu J. Pyrolysis/gasification of pine sawdust biomass briquettes under carbon dioxide atmosphere: Study on carbon dioxide reduction (utilization) and biochar briquettes physicochemical properties. Bioresource Technology 2018;249:983-91. [30] Speight JG. Handbook of Coal Analysis: John Wiley and Sons, Inc., Hoboken; 2005.

[31] Agblevor FA, Beis S, Kim SS, Tarrant R, Mante NO. Biocrude oils from the fast pyrolysis of poultry litter and hardwood. Waste management (New York, NY) 2010;30:298-307.

[32] Kim D, Yoshikawa K, Park K. Characteristics of Biochar Obtained by Hydrothermal Carbonization of Cellulose for Renewable Energy. Energies 2015;8:12412.

[33] Frederik R, Sven vH, Dane D, Wolter P. Production and characterization of slow pyrolysis biochar: influence of feedstock type and pyrolysis conditions. GCB Bioenergy 2013;5:104-15. [34] Gaskin JW, Steiner C, Harris K, C. Das K, Bibens B. Effect of Low-Temperature Pyrolysis Conditions on Biochar for Agricultural Use. Transactions of the ASABE 2008;51:2061-9.

[35] Kordoghli S, Khiari B, Paraschiv M, Zagrouba F, Tazerout M. Production of hydrogen and hydrogen-rich syngas during thermal catalytic supported cracking of waste tyres in a benchscale fixed bed reactor. International Journal of Hydrogen Energy 2018.

[36] Xu X, Zhao Y, Sima J, Zhao L, Mašek O, Cao X. Indispensable role of biochar-inherent mineral constituents in its environmental applications: A review. Bioresource Technology 2017;241:887-99.

[37] Hadrich B, Dimitrov K, Kriaa K. Modelling Investigation and Parameters Study of Polyphenols Extraction from Carob (Ceratonia siliqua L.) Using Experimental Factorial Design. Journal of Food Processing and Preservation 2017;41.

[38] Zhao N, Wei N, Li J, Qiao Z, Cui J, He F. Surface properties of chemically modified activated carbons for adsorption rate of Cr (VI). Chemical Engineering Journal 2005;115:1338. 
[39] Hass A, Gonzalez JM, Lima IM, Godwin HW, Halvorson JJ, Boyer DG. Chicken manure biochar as liming and nutrient source for acid Appalachian soil. Journal of environmental quality 2012;41:1096-106.

[40] Yuan J-H, Xu R-K, Zhang H. The forms of alkalis in the biochar produced from crop residues at different temperatures. Bioresource Technology 2011;102:3488-97.

[41] Stella Mary G, Sugumaran P, Niveditha S, Ramalakshmi B, Ravichandran P, Seshadri S. Production, characterization and evaluation of biochar from pod (Pisum sativum), leaf (Brassica oleracea) and peel (Citrus sinensis) wastes. International Journal of Recycling of Organic Waste in Agriculture 2016;5:43-53.

[42] Zhao S-X, Ta N, Wang X-D. Effect of Temperature on the Structural and Physicochemical Properties of Biochar with Apple Tree Branches as Feedstock Material. Energies 2017;10:1293. [43] Narzari R, Bordoloi N, Sarma B, Gogoi L, Gogoi N, Borkotoki B, et al. Fabrication of biochars obtained from valorization of biowaste and evaluation of its physicochemical properties. Bioresource Technology 2017;242:324-8.

[44] Zhang J, Wang Q. Sustainable mechanisms of biochar derived from brewers' spent grain and sewage sludge for ammonia-nitrogen capture. Journal of Cleaner Production 2016;112:3927-34.

[45] Cantrell KB, Hunt PG, Uchimiya M, Novak JM, Ro KS. Impact of pyrolysis temperature and manure source on physicochemical characteristics of biochar. Bioresource Technology 2012;107:419-28.

[46] Ronsse F, van Hecke S, Dickinson D, Prins W. Production and characterization of slow pyrolysis biochar: influence of feedstock type and pyrolysis conditions. GCB Bioenergy 2013;5:104-15.

[47] Brewer CE, Chuang VJ, Masiello CA, Gonnermann H, Gao X, Dugan B, et al. New approaches to measuring biochar density and porosity. Biomass and Bioenergy 2014;66:17685.

[48] Hagemann N, Spokas K, Schmidt H-P, Kägi R, Böhler M, Bucheli T. Activated Carbon, Biochar and Charcoal: Linkages and Synergies across Pyrogenic Carbon's ABCs. Water 2018;10:182.

[49] Fu P, Yi W, Bai X, Li Z, Hu S, Xiang J. Effect of temperature on gas composition and char structural features of pyrolyzed agricultural residues. Bioresource Technology 2011;102:82119.

[50] Jeguirim M, Limousy L, Dutournie P. Pyrolysis kinetics and physicochemical properties of agropellets produced from spent ground coffee blended with conventional biomass. Chemical Engineering Research and Design 2014;92:1876-82.

[51] Lajili M, Limousy L, Jeguirim M. Physico-chemical properties and thermal degradation characteristics of agropellets from olive mill by-products/sawdust blends. Fuel Processing Technology 2014;126:215-21.

[52] Hu Q, Yang H, Yao D, Zhu D, Wang X, Shao J, et al. The densification of bio-char: Effect of pyrolysis temperature on the qualities of pellets. Bioresource Technology 2016;200:521-7.

[53] Sotannde OA, Oluyege AO, Abah GB. Physical and combustion properties of briquettes from sawdust of Azadirachta indica. Journal of Forestry Research 2010;21:63-7.

[54] Wu S, Zhang S, Wang C, Mu C, Huang X. High-strength charcoal briquette preparation from hydrothermal pretreated biomass wastes. Fuel Processing Technology 2018;171:293-300. [55] https://www.globalsources.com/si/AS/Zhecheng-Jingxin/.

https://www.europages.co.uk/OLIVKETTS/00000004681861482315001/documentation.html.

[57] Division FI. Simple technologies for charcoal making. In: NATIONS FAAOOTU, editor. FAO FORESTRY PAPER 41. Rome1987. 
[58] Srivastava NSL, Narnaware SL, Makwana JP, Singh SN, Vahora S. Investigating the energy use of vegetable market waste by briquetting. Renewable Energy 2014;68:270-5.

[59] Islam MA, Kabir G, Asif M, Hameed BH. Combustion kinetics of hydrochar produced from hydrothermal carbonisation of Karanj (Pongamia pinnata) fruit hulls via thermogravimetric analysis. Bioresource Technology 2015;194:14-20.

[60] Zhou Z, Hu X, You Z, Wang Z, Zhou J, Cen K. Oxy-fuel combustion characteristics and kinetic parameters of lignite coal from thermo-gravimetric data. Thermochimica Acta 2013;553:54-9.

[61] Antal MJ, Grønli M. The Art, Science, and Technology of Charcoal Production. Industrial \& Engineering Chemistry Research 2003;42:1619-40.

[62] Islam MA, Asif M, Hameed BH. Pyrolysis kinetics of raw and hydrothermally carbonized Karanj (Pongamia pinnata) fruit hulls via thermogravimetric analysis. Bioresource Technology 2015;179:227-33.

[63] Román S, Nabais JMV, Laginhas C, Ledesma B, González JF. Hydrothermal carbonization as an effective way of densifying the energy content of biomass. Fuel Processing Technology 2012;103:78-83.

[64] Senneca O, Chirone R, Salatino P. A Thermogravimetric Study of Nonfossil Solid Fuels. 2. Oxidative Pyrolysis and Char Combustion. Energy \& Fuels 2002;16:661-8.

[65] Sima-Ella E, Yuan G, Mays T. A simple kinetic analysis to determine the intrinsic reactivity of coal chars. Fuel 2005;84:1920-5.

[66] Hirunpraditkoon S, Intharit S, Srisumran S, Wongvirojtana P. Combustion Properties of Briquette Charcoal from Durian Peel. Applied Mechanics and Materials 2014;666:41-5.

[67] Conag AT, Villahermosa JER, Cabatingan LK, Go AW. Energy densification of sugarcane bagasse through torrefaction under minimized oxidative atmosphere. Journal of Environmental Chemical Engineering 2017;5:5411-9.

[68] Han K, Wang Q, Zhao J, Luo KH, Li H, Chen Y, et al. Combustion pattern, characteristics, and kinetics of biomass and chars from segmented heating carbonization. Asia-Pacific Journal of Chemical Engineering 2016;11:812-22.

[69] He X-M, Yi S, Fu P-R, Zeng X-C, Zhang D, Cheng X-H. Combustion Reactivity of Biochar and Char Generated from Co-Pyrolysis of Coal and Four Additives: Application in Blast Furnace. Journal of Energy Engineering 2017;143:04016023.

[70] Niu S, Chen M, Li Y, Xue F. Evaluation on the oxy-fuel combustion behavior of dried sewage sludge. Fuel 2016;178:129-38.

[71] Wang Q, Han K, Gao J, Li H, Lu C. The pyrolysis of biomass briquettes: Effect of pyrolysis temperature and phosphorus additives on the quality and combustion of bio-char briquettes. Fuel 2017;199:488-96.

[72] Werkelin J, Skrifvars B-J, Zevenhoven M, Holmbom B, Hupa M. Chemical forms of ashforming elements in woody biomass fuels. Fuel 2010;89:481-93.

[73] Vamvuka D, Zografos D, Alevizos G. Control methods for mitigating biomass ash-related problems in fluidized beds. Bioresource Technology 2008;99:3534-44.

[74] Boström D, Skoglund N, Grimm A, Boman C, Öhman M, Broström M, et al. Ash Transformation Chemistry during Combustion of Biomass. Energy \& Fuels 2012;26:85-93.

[75] Khiari B, Kordoghli S, Mihoubi D, Zagrouba F, Tazerout M. Modeling kinetics and transport phenomena during multi-stage tire wastes pyrolysis using Comsol@. Waste Management 2018;78:337-45.

[76] Gao X, Wu H. Biochar as a Fuel: 4. Emission Behavior and Characteristics of PM1 and PM10 from the Combustion of Pulverized Biochar in a Drop-Tube Furnace. Energy \& Fuels 2011;25:2702-10.

[77] Huang H-L, Lee W-MG, Wu F-S. Emissions of air pollutants from indoor charcoal barbecue. Journal of Hazardous Materials 2016;302:198-207. 
[78] Qi J, Han K, Wang Q, Gao J. Carbonization of biomass: Effect of additives on alkali metals residue, SO2 and NO emission of chars during combustion. Energy 2017;130:560-9.

[79] Scala F, Salatino P, Chirone R. Fluidized Bed Combustion of a Biomass Char (Robinia pseudoacacia). Energy \& Fuels 2000;14:781-90.

[80] Scala F, Chirone R, Salatino P. Combustion and Attrition of Biomass Chars in a Fluidized Bed. Energy \& Fuels 2006;20:91-102.

[81] Chouchene A, Jeguirim M, Khiari B, Trouvé G, Zagrouba F. Study on the emission mechanism during devolatilization/char oxidation and direct oxidation of olive solid waste in a fixed bed reactor. Journal of Analytical and Applied Pyrolysis 2010;87:168-74.

[82] Wornat MJ, Hurt RH, Yang NYC, Headley TJ. Structural and compositional transformations of biomass chars during combustion. Combustion and Flame 1995;100:13143.

[83] Linderholm C, Schmitz M, Knutsson P, Källén M, Lyngfelt A. Use of Low-Volatile Solid Fuels in a 100 kW Chemical-Looping Combustor. Energy \& Fuels 2014;28:5942-52.

[84] Kong L, Tian S, Li Z, Luo R, Chen D, Tu Y, et al. Conversion of recycled sawdust into high HHV and low NOx emission bio-char pellets using lignin and calcium hydroxide blended binders. Renewable Energy 2013;60:559-65.

[85] Lewis JJ, Pattanayak SK. Who Adopts Improved Fuels and Cookstoves? A Systematic Review. Environmental Health Perspectives 2012;120:637-45.

[86] Winijkul E, Bond TC. Emissions from residential combustion considering end-uses and spatial constraints: Part II, emission reduction scenarios. Atmospheric Environment 2016;124:1-11.

[87] Bailis R, Berrueta V, Chengappa C, Dutta K, Edwards R, Masera O, et al. Performance testing for monitoring improved biomass stove interventions: experiences of the Household Energy and Health. Energy for Sustainable Development 2007;11:57-70.

[88] Bhattacharya SC, Albina DO, Myint Khaing A. Effects of selected parameters on performance and emission of biomass-fired cookstoves. Biomass and Bioenergy 2002;23:38795.

[89] Sevault A, Khalil RA, Enger BC, Skreiberg Ø, Goile F, Wang L, et al. Performance Evaluation of a Modern Wood Stove Using Charcoal. Energy Procedia 2017;142:192-7.

[90] Gallagher M, Beard M, Clifford MJ, Watson MC. An evaluation of a biomass stove safety protocol used for testing household cookstoves, in low and middle-income countries. Energy for Sustainable Development 2016;33:14-25.

[91] ENERGY FOR COOKING IN DEVELOPING COUNTRIES. World Energy Outlook Focus on key topics: OECD/EIA; 2006.

[92] Castro Díaz M, Zhao H, Kokonya S, Dufour A, Snape CE. The Effect of Biomass on Fluidity Development in Coking Blends Using High-Temperature SAOS Rheometry. Energy \& Fuels 2012;26:1767-75.

[93] Castro-Díaz M, Vega MF, Barriocanal C, Snape CE. Utilization of Carbonaceous Materials To Restore the Coking Properties of Weathered Coals. Energy \& Fuels 2015;29:5744-9.

[94] Kokonya S, Castro-Díaz M, Barriocanal C, Snape CE. An investigation into the effect of fast heating on fluidity development and coke quality for blends of coal and biomass. Biomass and Bioenergy 2013;56:295-306.

[95] MacPhee JA, Gransden JF, Giroux L, Price JT. Possible CO2 mitigation via addition of charcoal to coking coal blends. Fuel Processing Technology 2009;90:16-20.

[96] Thomas S, McKnight S, Serrano E, Mašlejová A, Želinský R, Tomáš J. Laboratory evaluation of biomass usage for coke and sinter production. METEC InSteelCon. Düsseldorf (Germany)2011. 
[97] Ng KW, Giroux L, MacPhee T, Todoschuk T. Incorporation of charcoal in coking coal blend-A study of the effects on carbonization conditions and coke quality. AISTech the iron \& steel technology conference2012. p. 225-36.

[98] Montiano MG, Díaz-Faes E, Barriocanal C, Alvarez R. Influence of biomass on metallurgical coke quality. Fuel 2014;116:175-82.

[99] Todoschek T, Giroux LW, Ng KW. Development of biocarbons for Canadian steel production. Biocleantech Forum2016.

[100] Lu L, Adam M, Somerville M, Hapugoda S, Jahanshahi S, Mathieson JG. Iron ore sintering with charcoal. 6th International Congress on the Science and Technology of Ironmaking2012. p. 1121-31.

[101] Ooi TC, Aries E, Ewan BCR, Thompson D, Anderson DR, Fisher R, et al. The study of sunflower seed husks as a fuel in the iron ore sintering process. Minerals Engineering 2008;21:167-77.

[102] Lovel R, Vining K, Dell'Amico M. Iron ore sintering with charcoal. Mineral Processing and Extractive Metallurgy 2007;116:85-92.

[103] Mousa E, Babich A, Senk D. Iron ore sintering process with biomass utilization. Proc of METEC \& 2nd ESTAT. Düsseldorf, Gemany2015.

[104] Naglaa AEH, Khalifa AA, El-Midany AA, Ahmed A, Shalabi MEH. Effect of replacement coke breeze by charcoal on technical operation of iron ore sintering. International Journal of Scientific \& Engineering Research 2015;6: 681-7.

[105] Lovel RR, Vining KR, Dell'Amico M. The influence of fuel reactivity on iron ore sintering. ISIJ international 2009;49(2): 195-202.

[106] Lovel RR, Vining KR, Dell 'amico M. The Influence of Fuel Reactivity on Iron Ore Sintering. ISIJ International 2009;49:195-202.

[107] Yokoyama H, Higuchi K, Ito T, Oshio A. Decrease in the Carbon Consumption of a Commercial Blast Furnace by Using Carbon Composite Iron Ore. Tetsu-to-Hagane 2014;100:601-9.

[108] Ahmed HM, Viswanathan N, Bjorkman B. Composite Pellets - A Potential Raw Material for Iron-Making. steel research international 2014;85:293-306.

[109] Guo D, Hu M, Pu C, Xiao B, Hu Z, Liu S, et al. Kinetics and mechanisms of direct reduction of iron ore-biomass composite pellets with hydrogen gas. International Journal of Hydrogen Energy 2015;40:4733-40.

[110] Rodd L, Koehler T, Walker C, Voermann N. Economics of slag heat recovery from ferronickel slags. Sustainability for Profit. Conference of Metallurgists (COM2010)2010. p. 317.

[111] Mathieson J. The value-in-use of some biomass-derived blast furnace injectants. Technote 2007.

[112] Yellishetty M, Mudd GM, Ranjith PG, Tharumarajah A. Environmental life-cycle comparisons of steel production and recycling: sustainability issues, problems and prospects. Environmental Science \& Policy 2011;14:650-63.

[113] Gil MV, García R, Pevida C, Rubiera F. Grindability and combustion behavior of coal and torrefied biomass blends. Bioresource Technology 2015;191:205-12.

[114] Schaefer S, Fierro V, Izquierdo MT, Celzard A. Assessment of hydrogen storage in activated carbons produced from hydrothermally treated organic materials. International Journal of Hydrogen Energy 2016;41:12146-56.

[115] Texier-Mandoki N, Dentzer J, Piquero T, Saadallah S, David P, Vix-Guterl C. Hydrogen storage in activated carbon materials: Role of the nanoporous texture. Carbon 2004;42:2744-7. [116] Machado JGMdS, Osório E, Vilela ACF. Reactivity of brazilian coal, charcoal, imported coal and blends aiming to their injection into blast furnaces. Materials Research 2010;13:28792. 
[117] Pohlmann JG, Borrego AG, Osório E, Diez MA, Vilela ACF. Combustion of eucalyptus charcoals and coals of similar volatile yields aiming at blast furnace injection in a $\mathrm{CO} 2$ mitigation environment. Journal of Cleaner Production 2016;129:1-11.

[118] Ueda S, Inoue R, Ariyama T. Control of Biomass Composition for Optimum Injection in Blast Furnace to Mitigate $\mathrm{CO}<\mathrm{sub}>2</ \mathrm{sub}>$ Emission in Ironmaking Process. Tetsu-to-Hagane 2008;94:468-74.

[119] Bohlin F. The Swedish carbon dioxide tax: effects on biofuel use and carbon dioxide emissions. Biomass and Bioenergy 1998;15:283-91.

[120] Feliciano C, Mathews JA. Bio-PCI a renewable reductant for blast furnaces: CO2 mitigation potential and economical assessment. Proceedings of the ICSTI122012. p. 1914-27. [121] Fidalgo B, Berrueco C, Millan M. Chars from agricultural wastes as greener fuels for electric arc furnaces. Journal of Analytical and Applied Pyrolysis 2015;113:274-80.

[122] Echterhof T, Pfeifer H. Potential of biomass usage in electric steelmaking. Proceedings of 1st International Conference on Energy Efficiency and CO2 Reduction in the Steel Industry2011.

[123] Yunos NFM, Zaharia M, Idris MA, Nath D, Khanna R, Sahajwalla V. Recycling Agricultural Waste from Palm Shells during Electric Arc Furnace Steelmaking. Energy \& Fuels 2012;26:278-86.

[124] Sakaranaho M, Heikkilä A, Suopajärvi H, Päätalo M, Fabritius T. Charcoal Use in Chromite Pellets - Effect on Sintering Process, Pellet Properties, and Electrical Conductivity. steel research international 2018;89:1700260.

[125] Bianco L, Baracchini G, Cirilli F, Sante LD, Moriconi A, Moriconi E, et al. Sustainable Electric Arc Furnace Steel Production: GREENEAF. BHM Berg- und Hüttenmännische Monatshefte 2013;158:17-23.

[126] Wibberley L, Nunn J, Scaife P, Zivlas A, Andrews L, Coomber B. Large scale use of forest biomass for iron and steelmaking. . NSW Government Sustainable Energy Research Development Fund (SERDF); 2001.

[127] Konishi H, Ichikawa K, Usui T. Effect of Residual Volatile Matter on Reduction of Iron Oxide in Semi-charcoal Composite Pellets. ISIJ International 2010;50:386-9.

[128] Luo S, Yi C, Zhou Y. Direct reduction of mixed biomass-Fe2O3 briquettes using biomass-generated syngas. Renewable Energy 2011;36:3332-6.

[129] Fu J-X, Zhang C, Hwang W-S, Liau Y-T, Lin Y-T. Exploration of biomass char for CO2 reduction in RHF process for steel production. International Journal of Greenhouse Gas Control 2012;8:143-9.

[130] Kumar M, Gupta RC. Industrial Uses of Wood Char. Energy Sources 1998;20:575-89.

[131] Cunningham Michael GM, Strande Linda. Literature review: Slow pyrolysis of feacal sludge. In: Zurich E, editor. Eawag aquatic research2016.

[132] Peters JF, Iribarren D, Dufour J. Biomass Pyrolysis for Biochar or Energy Applications? A Life Cycle Assessment. Environmental Science \& Technology 2015;49:5195-202.

[133] Ellem Gary K, Mulligan Cara J. Biomass char as a fuel for internal combustion engines. Asia-Pacific Journal of Chemical Engineering 2011;7:769-76.

[134] Rajamohan S, Kasimani R. Analytical characterization of products obtained from slow pyrolysis of Calophyllum inophyllum seed cake: study on performance and emission characteristics of direct injection diesel engine fuelled with bio-oil blends. Environmental science and pollution research international 2018;25:9523-38.

[135] Mulimani HV, Navindgi MC. Production of Solid Fuel Biochar from De-Oiled Seed Cake by Pyrolysis. Journal of Mechanical and Civil Engineering 2017;14:57-61.

[136] Soloiu V, Lewis J, Yoshihara Y, Nishiwaki K. Combustion characteristics of a charcoal slurry in a direct injection diesel engine and the impact on the injection system performance. Energy 2011;36:4353-71. 
[137] Norgate TEL, D.E. Environmental and economic aspects of charcoal use in steelmaking. ISIJ International 2009;49:587-95.

[138] Al-Qayim K, Nimmo W, Hughes K, Pourkashanian M. Kinetic parameters of the intrinsic reactivity of woody biomass and coal chars via thermogravimetric analysis. Fuel 2017;210:81125.

[139] Gupta A, Thengane SK, Mahajani S. CO2 gasification of char from lignocellulosic garden waste: Experimental and kinetic study. Bioresource Technology 2018;263:180-91.

[140] Septien S, Escudero Sanz FJ, Salvador S, Valin S. The effect of pyrolysis heating rate on the steam gasification reactivity of char from woodchips. Energy 2018;142:68-78.

[141] Lu P, Huang Q, Bourtsalas AC, Chi Y, Yan J. Experimental research of basic properties and reactivity of waste derived chars. Applied Thermal Engineering 2017;119:639-49.

[142] Lajili M, Guizani C, Escudero Sanz FJ, Jeguirim M. Fast pyrolysis and steam gasification of pellets prepared from olive oil mill residues. Energy 2018;150:61-8.

[143] Di Blasi C. Combustion and gasification rates of lignocellulosic chars. Progress in Energy and Combustion Science 2009;35:121-40.

[144] Le CD, Kolaczkowski ST. Steam gasification of a refuse derived char: Reactivity and kinetics. Chemical Engineering Research and Design 2015;102:389-98.

[145] Tilghman MB, Mitchell RE. Coal and biomass char reactivities in gasification and combustion environments. Combustion and Flame 2015;162:3220-35.

[146] https://eprenewable.com/wp-content/uploads/2019/01/ATEC-White-Paper-Jan2019.pdf.

[147] https://www.netl.doe.gov/research/Coal/energy-systems/gasification/gasifipedia/typesgasifiers.

[148] Lindauer G KT. A 4 to 6-MW wood gasification unit: scaling-up the gasification technology into an unknown size category (Case study Guyana). . Energy from biomass 1981. p. $782-8$.

[149] http://www.auri.org/2010/04/char-crossed-fuel/.

[150] Handbook of Biomass Downdraft Gasifier Engine Systems SERIISP-271-3022 DE88001135 March 1988

[151]

http://www.bine.info/en/press/press-releases/archive-pressreleases/pressemitteilung/biokohle-in-brenngas-umwandeln/.

[152] Tamošiūnas A, Valatkevičius P, Gimžauskaitè D, Valinčius V, Jeguirim M. Glycerol steam reforming for hydrogen and synthesis gas production. International Journal of Hydrogen Energy 2017;42:12896-904.

[153] Tamosiunas A, Valatkevicius P, Gimzauskaite D, Jeguirim M, Mecius V, Aikas M. Energy recovery from waste glycerol by utilizing thermal water vapor plasma. Environmental science and pollution research international 2017;24:10030-40.

[154] Kordoghli S, Paraschiv M, Tazerout M, Khiari B, Zagrouba F. Novel Catalytic Systems for Waste Tires Pyrolysis: Optimization of Gas Fraction. Journal of Energy Resources Technology, Transactions of the ASME 2017;139.

[155] Klinghoffer NB, Castaldi MJ, Nzihou A. Influence of char composition and inorganics on catalytic activity of char from biomass gasification. Fuel 2015;157:37-47.

[156] Song Y, Wang Y, Hu X, Hu S, Xiang J, Zhang L, et al. Effects of volatile-char interactions on in situ destruction of nascent tar during the pyrolysis and gasification of biomass. Part I. Roles of nascent char. Fuel 2014;122:60-6.

[157] Syed-Hassan SSA, Fuadi FA. Catalytic Steam Reforming of Biomass Tar Model Compound Using Nickel and Cobalt Catalysts Supported on Palm Kernel Shell Char. JOURNAL OF CHEMICAL ENGINEERING OF JAPAN 2016;49:29-34. 
[158] Widayatno WB, Guan G, Rizkiana J, Hao X, Wang Z, Samart C, et al. Steam reforming of tar derived from Fallopia Japonica stem over its own chars prepared at different conditions. Fuel 2014;132:204-10.

[159] Li L, Song Z, Zhao X, Ma C, Kong X, Wang F. Microwave-induced cracking and CO2 reforming of toluene on biomass derived char. Chemical Engineering Journal 2016;284:130816.

[160] Wang D, Yuan W, Ji W. Char and char-supported nickel catalysts for secondary syngas cleanup and conditioning. Applied Energy 2011;88:1656-63.

[161] Shen Y. Chars as carbonaceous adsorbents/catalysts for tar elimination during biomass pyrolysis or gasification. Renewable and Sustainable Energy Reviews 2015;43:281-95.

[162] Shen Y, Yoshikawa K. Tar Conversion and Vapor Upgrading via in Situ Catalysis Using Silica-Based Nickel Nanoparticles Embedded in Rice Husk Char for Biomass Pyrolysis/Gasification. Industrial \& Engineering Chemistry Research 2014;53:10929-42.

[163] Zhang X, Wilson K, Lee AF. Heterogeneously Catalyzed Hydrothermal Processing of C5-C6 Sugars. Chemical Reviews 2016;116:12328-68.

[164] Bhandari PN, Kumar A, Bellmer DD, Huhnke RL. Synthesis and evaluation of biocharderived catalysts for removal of toluene (model tar) from biomass-generated producer gas. Renewable Energy 2014;66:346-53.

[165] Min Z, Zhang S, Yimsiri P, Wang Y, Asadullah M, Li C-Z. Catalytic reforming of tar during gasification. Part IV. Changes in the structure of char in the char-supported iron catalyst during reforming. Fuel 2013;106:858-63.

[166] Ma Z, Xiao R, Zhang H. Catalytic steam reforming of bio-oil model compounds for hydrogen-rich gas production using bio-char as catalyst. International Journal of Hydrogen Energy 2017;42:3579-85.

[167] Safari F, Norouzi O, Tavasoli A. Hydrothermal gasification of Cladophora glomerata macroalgae over its hydrochar as a catalyst for hydrogen-rich gas production. Bioresour Technol 2016;222:232-41.

[168] Yao D, Hu Q, Wang D, Yang H, Wu C, Wang X, et al. Hydrogen production from biomass gasification using biochar as a catalyst/support. Bioresource Technology 2016;216:159-64.

[169] Cai J, Bennici S, Shen J, Auroux A. The influence of metal- and N-species addition in mesoporous carbons on the hydrogen adsorption capacity. Materials Chemistry and Physics 2015;161:142-52.

[170] Feroldi M, Neves AC, Borba CE, Alves HJ. Methane storage in activated carbon at low pressure under different temperatures and flow rates of charge. Journal of Cleaner Production 2018;172:921-6.

[171] Li Y, Li D, Rao Y, Zhao X, Wu M. Superior CO2, CH4, and H2 uptakes over ultrahighsurface-area carbon spheres prepared from sustainable biomass-derived char by $\mathrm{CO} 2$ activation. Carbon 2016;105:454-62.

[172] Arami-Niya A, Wan Daud WMA, S. Mjalli F, Abnisa F, Shafeeyan MS. Production of microporous palm shell based activated carbon for methane adsorption: Modeling and optimization using response surface methodology. Chemical Engineering Research and Design 2012;90:776-84.

[173] Bagheri N, Abedi J. Adsorption of methane on corn cobs based activated carbon. Chemical Engineering Research and Design 2011;89:2038-43.

[174] Policicchio A, Maccallini E, Agostino RG, Ciuchi F, Aloise A, Giordano G. Higher methane storage at low pressure and room temperature in new easily scalable large-scale production activated carbon for static and vehicular applications. Fuel 2013;104:813-21. 
[175] Ruiz B, Ferrera-Lorenzo N, Fuente E. Valorisation of lignocellulosic wastes from the candied chestnut industry. Sustainable activated carbons for environmental applications. Journal of Environmental Chemical Engineering 2017;5:1504-15.

[176] Matranga KR, Myers AL, Glandt ED. Storage of natural gas by adsorption on activated carbon. Chemical Engineering Science 1992;47:1569-79.

[177] Blankenship Ii TS, Balahmar N, Mokaya R. Oxygen-rich microporous carbons with exceptional hydrogen storage capacity. Nature Communications 2017;8:1545.

[178] Heo Y-J, Park S-J. Synthesis of activated carbon derived from rice husks for improving hydrogen storage capacity. Journal of Industrial and Engineering Chemistry 2015;31:330-4.

[179] Ramesh T, Rajalakshmi N, Dhathathreyan KS. Synthesis and characterization of activated carbon from jute fibers for hydrogen storage. Renew Energy Environ Sustain 2017;2:4.

[180] Ramesh T, Rajalakshmi N, Dhathathreyan KS. Activated carbons derived from tamarind seeds for hydrogen storage. Journal of Energy Storage 2015;4:89-95.

[181] Li G, Li J, Tan W, Jin H, Yang H, Peng J, et al. Preparation and characterization of the hydrogen storage activated carbon from coffee shell by microwave irradiation and $\mathrm{KOH}$ activation. International Biodeterioration \& Biodegradation 2016;113:386-90.

[182] Bader N, Abdelmottaleb O. CO2 activation of olive bagasse for hydrogen storage. Environmental Progress \& Sustainable Energy 2017;36:315-24.

[183] Md Arshad SH, Ngadi N, Aziz AA, Amin NS, Jusoh M, Wong S. Preparation of activated carbon from empty fruit bunch for hydrogen storage. Journal of Energy Storage 2016;8:25761 .

[184] Balathanigaimani MS, Haider MB, Jha D, Kumar R, Lee SJ, Shim WG, et al. Nanostructured Biomass Based Carbon Materials from Beer Lees for Hydrogen Storage. Journal of nanoscience and nanotechnology 2018;18:2196-9.

[185] Andrews J, Shabani B. The role of hydrogen in a global sustainable energy strategy. Wiley Interdisciplinary Reviews: Energy and Environment 2014;3:474-89.

[186] Wang J, Senkovska I, Kaskel S, Liu Q. Chemically activated fungi-based porous carbons for hydrogen storage. Carbon 2014;75:372-80.

[187] Liu X, Zhang C, Geng Z, Cai M. High-pressure hydrogen storage and optimizing fabrication of corncob-derived activated carbon. Microporous and Mesoporous Materials 2014;194:60-5.

[188] Wróbel-Iwaniec I, Díez N, Gryglewicz G. Chitosan-based highly activated carbons for hydrogen storage. International Journal of Hydrogen Energy 2015;40:5788-96.

[189] Zhang J, Gao J, Chen Y, Hao X, Jin X. Characterization, preparation, and reaction mechanism of hemp stem based activated carbon. Results in Physics 2017;7:1628-33.

[190] Wang H, Gao Q, Hu J. High Hydrogen Storage Capacity of Porous Carbons Prepared by Using Activated Carbon. Journal of the American Chemical Society 2009;131:7016-22.

[191] Bader N, Ouederni A. Functionalized and metal-doped biomass-derived activated carbons for energy storage application. Journal of Energy Storage 2017;13:268-76.

[192] Xiao Y, Dong H, Long C, Zheng M, Lei B, Zhang H, et al. Melaleuca bark based porous carbons for hydrogen storage. International Journal of Hydrogen Energy 2014;39:11661-7.

[193] Rolison DR, Long JW, Lytle JC, Fischer AE, Rhodes CP, McEvoy TM, et al. Multifunctional 3D nanoarchitectures for energy storage and conversion. Chemical Society reviews 2009;38:226-52.

[194] Rufford TE, Hulicova-Jurcakova D, Zhu Z, Lu GQ. Nanoporous carbon electrode from waste coffee beans for high performance supercapacitors. Electrochemistry Communications 2008;10:1594-7.

[195] Li X, Xing W, Zhuo S, Zhou J, Li F, Qiao S-Z, et al. Preparation of capacitor's electrode from sunflower seed shell. Bioresource Technology 2011;102:1118-23. 
[196] Subramanian V, Luo C, Stephan AM, Nahm KS, Thomas S, Wei B. Supercapacitors from Activated Carbon Derived from Banana Fibers. The Journal of Physical Chemistry C 2007;111:7527-31.

[197] Rufford TE, Hulicova-Jurcakova D, Khosla K, Zhu Z, Lu GQ. Microstructure and electrochemical double-layer capacitance of carbon electrodes prepared by zinc chloride activation of sugar cane bagasse. Journal of Power Sources 2010;195:912-8.

[198] Jisha MR, Hwang YJ, Shin JS, Nahm KS, Prem Kumar T, Karthikeyan K, et al. Electrochemical characterization of supercapacitors based on carbons derived from coffee shells. Materials Chemistry and Physics 2009;115:33-9.

[199] Biswal M, Banerjee A, Deo M, Ogale S. From dead leaves to high energy density supercapacitors. Energy \& Environmental Science 2013;6:1249-59.

[200] Balathanigaimani MS, Shim W-G, Lee M-J, Kim C, Lee J-W, Moon H. Highly porous electrodes from novel corn grains-based activated carbons for electrical double layer capacitors. Electrochemistry Communications 2008;10:868-71.

[201] Basri NH, Deraman M, Kanwal S, Talib IA, Manjunatha JG, Aziz AA, et al. Supercapacitors using binderless composite monolith electrodes from carbon nanotubes and pre-carbonized biomass residues. Biomass and Bioenergy 2013;59:370-9.

[202] Xia X, Liu H, Shi L, He Y. Tobacco Stem-Based Activated Carbons for High Performance Supercapacitors. Journal of Materials Engineering and Performance 2012;21:1956-61.

[203] Chen M, Kang X, Wumaier T, Dou J, Gao B, Han Y, et al. Preparation of activated carbon from cotton stalk and its application in supercapacitor. Journal of Solid State Electrochemistry 2013;17:1005-12.

[204] Wang R, Wang P, Yan X, Lang J, Peng C, Xue Q. Promising Porous Carbon Derived from Celtuce Leaves with Outstanding Supercapacitance and CO2 Capture Performance. ACS Applied Materials \& Interfaces 2012;4:5800-6.

[205] He X, Ling P, Yu M, Wang X, Zhang X, Zheng M. Rice husk-derived porous carbons with high capacitance by $\mathrm{ZnCl} 2$ activation for supercapacitors. Electrochimica Acta 2013;105:635-41.

[206] Kim C, Lee J-W, Kim J-H, Yang K-S. Feasibility of bamboo-based activated carbons for an electrochemical supercapacitor electrode. Korean Journal of Chemical Engineering 2006;23:592-4.

[207] Kalpana D, Cho SH, Lee SB, Lee YS, Misra R, Renganathan NG. Recycled waste paper-A new source of raw material for electric double-layer capacitors. Journal of Power Sources 2009;190:587-91.

[208] Mi J, Wang X-R, Fan R-J, Qu W-H, Li W-C. Coconut-Shell-Based Porous Carbons with a Tunable Micro/Mesopore Ratio for High-Performance Supercapacitors. Energy \& Fuels 2012;26:5321-9.

[209] Hu C-C, Wang C-C, Wu F-C, Tseng R-L. Characterization of pistachio shell-derived carbons activated by a combination of $\mathrm{KOH}$ and $\mathrm{CO} 2$ for electric double-layer capacitors. Electrochimica Acta 2007;52:2498-505.

[210] Peng C, Yan X-b, Wang R-t, Lang J-w, Ou Y-j, Xue Q-j. Promising activated carbons derived from waste tea-leaves and their application in high performance supercapacitors electrodes. Electrochimica Acta 2013;87:401-8.

[211] Kurniawan F, Wongso M, Ayucitra A, Soetaredjo FE, Angkawijaya AE, Ju Y-H, et al. Carbon microsphere from water hyacinth for supercapacitor electrode. Journal of the Taiwan Institute of Chemical Engineers 2015;47:197-201.

[212] Senthilkumar ST, Selvan RK, Lee YS, Melo JS. Electric double layer capacitor and its improved specific capacitance using redox additive electrolyte. Journal of Materials Chemistry A 2013;1:1086-95. 
[213] Wu K, Gao B, Su J, Peng X, Zhang X, Fu J, et al. Large and porous carbon sheets derived from water hyacinth for high-performance supercapacitors. RSC Advances 2016;6:2999630003.

[214] Zhao Y-Q, Lu M, Tao P-Y, Zhang Y-J, Gong X-T, Yang Z, et al. Hierarchically porous and heteroatom doped carbon derived from tobacco rods for supercapacitors. Journal of Power Sources 2016;307:391-400.

[215] Wang H, Xu Z, Kohandehghan A, Li Z, Cui K, Tan X, et al. Interconnected Carbon Nanosheets Derived from Hemp for Ultrafast Supercapacitors with High Energy. ACS Nano 2013;7:5131-41.

[216] Elmouwahidi A, Zapata-Benabithe Z, Carrasco-Marín F, Moreno-Castilla C. Activated carbons from $\mathrm{KOH}$-activation of argan (Argania spinosa) seed shells as supercapacitor electrodes. Bioresource Technology 2012;111:185-90.

[217] Li J, Zan G, Wu Q. Nitrogen and sulfur self-doped porous carbon from brussel sprouts as electrode materials for high stable supercapacitors. RSC Advances 2016;6:57464-72.

[218] He S, Chen W. Application of biomass-derived flexible carbon cloth coated with $\mathrm{MnO} 2$ nanosheets in supercapacitors. Journal of Power Sources 2015;294:150-8.

[219] Wang L, Zheng Y, Chen S, Ye Y, Xu F, Tan H, et al. Three-Dimensional Kenaf StemDerived Porous Carbon/MnO2 for High-Performance Supercapacitors. Electrochimica Acta 2014;135:380-7.

[220] Xiong W, Gao Y, Wu X, Hu X, Lan D, Chen Y, et al. Composite of Macroporous Carbon with Honeycomb-Like Structure from Mollusc Shell and NiCo2O4 Nanowires for HighPerformance Supercapacitor. ACS Applied Materials \& Interfaces 2014;6:19416-23.

[221] Rosenman A, Markevich E, Salitra G, Aurbach D, Garsuch A, Chesneau FF. Review on Li-Sulfur Battery Systems: an Integral Perspective. Advanced Energy Materials 2015;5:1500212.

[222] Wang D-W, Zeng Q, Zhou G, Yin L, Li F, Cheng H-M, et al. Carbon-sulfur composites for Li-S batteries: status and prospects. Journal of Materials Chemistry A 2013;1:9382-94.

[223] Xu G, Ding B, Pan J, Nie P, Shen L, Zhang X. High performance lithium-sulfur batteries: advances and challenges. Journal of Materials Chemistry A 2014;2:12662-76.

[224] Moreno N, Caballero A, Hernán L, Morales J. Lithium-sulfur batteries with activated carbons derived from olive stones. Carbon 2014;70:241-8.

[225] Wang W, Sun Y, Liu B, Wang S, Cao M. Porous carbon nanofiber webs derived from bacterial cellulose as an anode for high performance lithium ion batteries. Carbon 2015;91:5665 .

[226] Ou J, Zhang Y, Chen L, Zhao Q, Meng Y, Guo Y, et al. Nitrogen-rich porous carbon derived from biomass as a high performance anode material for lithium ion batteries. Journal of Materials Chemistry A 2015;3:6534-41.

[227] Wu L, Buchholz D, Vaalma C, Giffin GA, Passerini S. Apple-Biowaste-Derived Hard Carbon as a Powerful Anode Material for Na-Ion Batteries. ChemElectroChem 2016;3:292-8. [228] Sun N, Liu H, Xu B. Facile synthesis of high performance hard carbon anode materials for sodium ion batteries. Journal of Materials Chemistry A 2015;3:20560-6.

[229] Ahn SY, Eom SY, Rhie YH, Sung YM, Moon CE, Choi GM, et al. Utilization of wood biomass char in a direct carbon fuel cell (DCFC) system. Applied Energy 2013;105:207-16.

[230] Lim S-H, Yong S-T, Ooi C-W, Chai S-P, Doshi V, Daud WRW. Pyrolysis of Palm Waste for the Application of Direct Carbon Fuel Cell. Energy Procedia 2014;61:878-81.

[231] El-kharouf A, Chandan A, Hattenberger M, Pollet BG. Proton exchange membrane fuel cell degradation and testing: review. Journal of the Energy Institute 2012;85:188-200.

[232] Moqsud MA, Omine K, Yasufuku N, Hyodo M, Nakata Y. Microbial fuel cell (MFC) for bioelectricity generation from organic wastes. Waste management (New York, NY) 2013;33:2465-9. 
[233] Wang Y, Chen W, Chen Y, Wei B, Chen L, Peng L, et al. Carbon-based catalysts by structural manipulation with iron for oxygen reduction reaction. Journal of Materials Chemistry A 2018;6:8405-12.

[234] Nieva Lobos ML, Sieben JM, Comignani V, Duarte M, Volpe MA, Moyano EL. Biochar from pyrolysis of cellulose: An alternative catalyst support for the electro-oxidation of methanol. International Journal of Hydrogen Energy 2016;41:10695-706. 